\title{
John Stearne's Confirmation and Discovery of Witchcraft
}

Between 1645 and 1647, John Stearne led the most significant outbreak of witch-hunting in England. As accusations of witchcraft spread across East Anglia, Stearne and Matthew Hopkins were enlisted by villagers to identify and eradicate witches. After the trials finally subsided in 1648 , Stearne wrote his only publication, A confirmation and discovery of witchcraft, but it had a limited readership. Consequently, Stearne and his work fell into obscurity until the 1800s and were greatly overshadowed by Hopkins and his text.

This book is the first study which analyses Stearne's publication and contextualises his ideas within early modern intellectual cultures of religion, demonology, gender, science, and print in order to better understand the witch-finder's beliefs and motives. The book argues that Stearne was a key player in the trials, that he was not a mainstream 'puritan', and that his witch-finding availed from contemporary science. It traces A confirmation's reception history from 1648 to modern day and argues that the lack of research focussing on Stearne has resulted in misrepresentations of the witch-finder in the historiography of witchcraft. This book redresses the imbalance and seeks to provide an alternative reading of the East Anglian witch-hunt and of England's premier witch-hunter, John Stearne.

Scott Eaton teaches history at Queen's University Belfast. He is a religious and cultural historian, with a particular interest in early modern witchcraft, magic, art, and print cultures. 


\section{Routledge Research in Early Modern History}

Religious Tolerance from Renaissance to Enlightenment Atheist's Progress

Eric MacPhail

Protestant Resistance in Counterreformation Austria Peter Thaler

Prosecuting Homicide in Eighteenth-Century Law and Practice

"And Must They All Be Hanged?"

Drew D. Gray

Making the Union Work

Scotland, 1651-1763

Alexander Murdoch

Major-General Hezekiah Haynes and the Failure of Oliver Cromwell's Godly Revolution, 1594-1704

David Farr

John Stearne's Confirmation and Discovery of Witchcraft

Text, Context and Afterlife

Scott Eaton

From Classical to Modern Republicanism

Reflections on England, Scotland, America, and France

Mark Hulliung

For more information about this series, please visit: https://www.routledge. com/Routledge-Research-in-Early-Modern-History/book-series/RREMH 


\title{
John Stearne's Confirmation and Discovery of Witchcraft Text, Context and Afterlife
}

\section{Scott Eaton}

\author{
Routledge \\ 两 Taylor \& Francis Group \\ NEW YORK AND LONDON
}


First published 2020

by Routledge

52 Vanderbilt Avenue, New York, NY 10017

and by Routledge

2 Park Square, Milton Park, Abingdon, Oxon OX14 4RN

Routledge is an imprint of the Taylor \& Francis Group, an informa business

(C) 2020 Scott Eaton

The right of Scott Eaton to be identified as author of this work has been asserted by him in accordance with sections 77 and 78 of the Copyright, Designs and Patents Act 1988.

All rights reserved. No part of this book may be reprinted or reproduced or utilised in any form or by any electronic, mechanical, or other means, now known or hereafter invented, including photocopying and recording, or in any information storage or retrieval system, without permission in writing from the publishers.

Trademark notice: Product or corporate names may be trademarks or registered trademarks, and are used only for identification and explanation without intent to infringe.

Library of Congress Cataloging-in-Publication Data

A catalog record has been requested for this book

ISBN: 978-0-367-89404-7 (hbk)

ISBN: 978-1-003-01900-8 (ebk)

Typeset in Sabon

by codeMantra 


\section{Contents}

List of Illustrations vii

Acknowledgements ix

Introduction 1

1 The Background of the East Anglian

Witch-Hunt: The Economy, Courts, Religion, and the Beginnings of the Trials

2 Puritanism: A Comparison of Stearne's Religious

Beliefs to the Orthodoxy of the Westminster Assembly's Confession of faith

3 Print Culture: The Literature of the Supernatural and the Reception of A confirmation

4 Familiar Spirits: The Origins of Stearne's Concept of Familiars and Its Symbolisms

5 Witchcraft, Sex, and Gender: Witchcraft Confessions in A confirmation as a Reflection of Seventeenth-Century Gender Roles

6 Science and the Decline of Witchcraft Beliefs: Evidence for the Scientific Basis of Stearne's

Witch-Finding 
vi Contents

7 The Afterlife of A confirmation: The Circulation and Rediscovery of Stearne's Text in the Nineteenth Century

Conclusion

173

Bibliography

Index 


\section{Illustrations}

\section{Figures}

I.1 John Stearne, A confirmation and discovery of witchcraft (London, 1648), Houghton Library, Harvard University, GEN 24244.74

2.1 Westminster confession of faith ([Edinburgh] 1647),

Folger Shakespeare Library, Washington DC, call number: W1430 (CC BY-SA 4.0)

A3.1 Number of printed texts in early modern England

A3.2 Percentage of publications mentioning 'witchcraft' (both for and against) in relation to all printed texts

A4.1 Mentions of 'familiar spirits' in print

A4.2 Mentions of 'familiar spirits' in print as a percentage of each decade's total printed works

5.1 Witches giving babies to the devil (1720). Credit:

Wellcome Collection, London (CC BY)

6.1 Matthew Hopkins, The discovery of witches (London, 1647), Folger Shakespeare Library, Washington DC, call number: 144-461q (CC BY-SA 4.0)

Table

A7.1 Extant copies of Stearne's Confirmation 


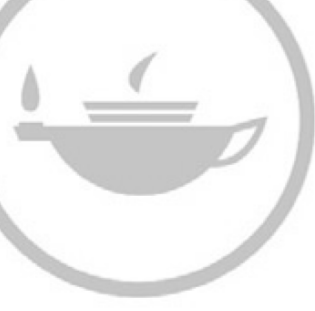

Taylor \& Francis Taylor \& Francis Group

http://taylorandfrancis.com 


\section{Acknowledgements}

As with most books, I have collected many debts while researching and writing about John Stearne. I am grateful to my friends and family for supporting me throughout, especially my wife Jen, my mother Susan, and my grandfather Gerry, who read various versions of each chapter, and to my father Jimmy, my grandmother Jean, and Jonny for being sounding boards. I am also indebted to Crawford Gribben and Stephen Kelly for their guidance, supervising my doctoral thesis, and providing references and insightful comments on drafts of each section. Additionally, I would like to thank Ian Campbell, Susan Hardman Moore, Chris Marsh, Scott Dixon, and Andrew Sneddon for their advice; Hannah Gibson for everything Teaching Assistant related; and the staff and students at Queen's University Belfast (QUB) who helped along the way.

I am also grateful to Santander for granting me a travel scholarship that enabled me to consult crucial archival materials, and to the Folger Shakespeare Library for funding and delivering specialist training through their English Palaeography Course. Staff in the special collections at the University of Glasgow, the British Library, Oxford Queen's College, Harvard Houghton Library, and librarians at QUB were all immensely helpful in sourcing the materials used in this book. Without the aid of everyone mentioned, plus many more, this book would not have been possible. 


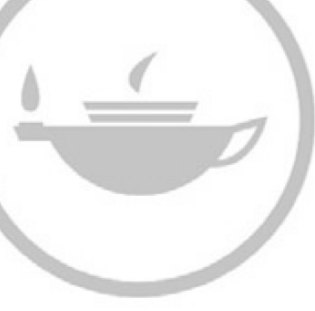

Taylor \& Francis Taylor \& Francis Group

http://taylorandfrancis.com 


\section{Introduction}

In March 1645, two witch-finders emerged from the town of Manningtree, Essex, and began a systematic pursuit of witches. Matthew Hopkins and John Stearne were minor gentlemen from the same locality and both had a puritan ethos. Their shared religious outlook may have inspired them to begin witch-hunting, in an attempt to restore harmony to communities that had been impacted by the experience of the First Civil War. Their method was to identify and eject witches from local communities, using scripture as guidance. They did so while operating within a traditional discourse of supernatural activity, and in their pursuit of witches they solicited testimonies of familiar spirits that sat uneasily with the Biblicist trajectory of mainstream puritan culture. ${ }^{1}$ Nonetheless, the confessions extracted from suspected witches provided sufficient evidence for conviction in many cases: from 1645 to 1647, Hopkins and Stearne aided in the investigation of 240 individuals who were suspected of witchcraft - half of whom were executed. ${ }^{2}$ The activities of the witch-finders were recorded in several contemporary pamphlets, which circulated widely in the expanding print culture of south-east England. Two of these pamphlets were authored by Hopkins and Stearne, and these texts illuminate the witch-finders' convictions and motives. They are especially useful for constructing a picture of John Stearne, whose sole publication, A confirmation and discovery witchcraft (1648), is the focal point of this book.

Little is known of John Stearne before his witch-hunting days. Much what we do know has been summarised and expanded by Malcolm Gaskill's Witchfinders (2005) - a popular history of the East Anglian witchcraft trials. The manuscripts Gaskill used to construct a biography of Stearne are scattered across south-east England and can be found in the Bodleian Library (Oxford), the West Suffolk Record Office (Bury St Edmunds), the East Suffolk Record Office (Ipswich), the Public Record Office (National Archives, Kew), and the Essex Record Office (Chelmsford). ${ }^{3}$ Although information on Stearne's biography is fragmentary, it is certain that he was born around 1610 and died in January 1670. Stearne came from a family of gentry and divines that can be traced to Cambridge during the fifteenth century. In the sixteenth century, the Stearnes branched 


\section{Introduction}

out from Cambridge into Norwich, Norfolk, Essex, and eventually Suffolk. Stearne's sister, however, did not travel far and was still living in Fordham, Cambridge, in $1662 .{ }^{4}$ During Stearne's life he had a wife named Agnes Cawston (or Causton) with whom he had seven children. Their first child, a girl, was born early in 1644 and their second, named Mary, was born in January 1648. Stearne and his family lived in Lawshall, Suffolk, near Bury St Edmunds, may have rented out a house in nearby Manningtree and held land in Little Clacton, Essex. ${ }^{5}$ Historians have tended to describe him as a man of the lower gentry who was a staunch puritan with a 'censorious manner', the latter partially due to his involvement in legal trials in the 1640s and 1650s. ${ }^{6}$ Unfortunately his occupation in the 1640s is unknown, but by 1662 he was a scribe or 'sometymes servant to Mr Cabeck of Herringswell', the long standing Presbyterian minister of St James Church, Bury St Edmunds (now St Edmundsbury Cathedral). ${ }^{7}$ In the 1640s, however, Stearne was held in esteem by the locals of Manningtree and was a politically significant individual who had connections to the local magistrates Sir Harbottle Grimston, 1st Baronet of Bradfield, Essex, and Sir Thomas Bowes. According to Stearne's account, the first woman suspected of being a witch, Elizabeth Clarke, was interrogated by townsmen until she confessed. The locals then approached Stearne and asked him to corroborate their findings with his own investigation. The evidence gathered by Stearne and the locals was taken to the magistrates, Bowes and Grimston, who readily gave Stearne permission to search for additional witches. It is interesting to note that both witch-finders claim to have been the instigators of the hunt, providing two possible scenarios. Hopkins maintained that he discovered a witches' gathering near his house, where he heard a witch talking to her imps. Hopkins implied that he reported this to the magistrates and started the hunt. The historian Frances Timbers, however, believes Stearne was the initiator of the investigations, not Hopkins, based on a critical piece of textual evidence. Timbers points out that Elizabeth Clarke threatened to kill Stearne with a toad-shaped familiar because he 'would have swome her' - her anger was clearly directed towards Stearne. ${ }^{8}$ According to Timbers's argument, Stearne would have encountered Clarke during his preliminary investigation, which took place without Hopkins. This hypothesis is strengthened by extant legal records. Although these records are not complete, as far as we can tell, a tailor from Manningtree named John Rivet was the first to accuse Elizabeth Clarke of witchcraft, and of bewitching his wife to death. In this light Hopkins seems less instrumental in beginning the East Anglian witch-hunt; the onus for that rests upon others, such as Rivet, Stearne, and the local magistrates. Throughout the trials, Hopkins and Stearne played their part in extracting confessions from suspected witches, but communities had already identified local witches prior to their arrival. In many cases the witch-finders confirmed pre-existing suspicions and made attempts to secure successful prosecutions at the assizes. The witch-hunt was therefore a collaborative 
effort to eject witches from local communities, not the will of an individual or a small group of individuals.

At the beginning of the witch-hunt, two magistrates gave witch-finding their approval, and therefore credence. But the magistrates Bowes and Grimston were by no means credulous Justices of the Peace (JPs). In 1638 Grimston condemned three women to death for practicing witchcraft, and Bowes had been involved in a witchcraft trial in 1642. When the official trials did begin in July 1645, Grimston, Bowes, and Robert Rich, the Earl of Warwick, sentenced nineteen to death (see Chapter 1 for more detail). ${ }^{9}$ But some of the local population shared the magistrates' concerns over witchcraft. Indeed, in Essex in the summer of 1645, over ninety individuals came forward to testify against suspected witches; therefore, it is not surprising that the magistrates passed a warrant enabling Stearne to investigate others since it elicited popular enthusiasm. ${ }^{10}$ Effective witch-hunting required participation from many individuals from all levels of society, to identify and testify against suspects. Such support was readily found in East Anglia. ${ }^{11}$

Once the witch-finding warrant was enacted, Hopkins appeared and offered Stearne his aid. Then the witch-hunt quickly branched out from Manningtree. ${ }^{12}$ After Stearne, Hopkins and their female searchers successfully discovered local witches, they moved on to Great Wenham and went their separate ways. Hopkins headed east and Stearne went west, never straying too far from his family in Lawshall. The witch-hunters met each other when they were summoned to court to testify against witches at the assize courts, which probably amounts to a few occasions, but otherwise they worked independently. ${ }^{13}$ Hopkins eventually died of 'consumption' (tuberculosis) on 12 August $1647 .^{14}$ In the same year Hopkins published his pamphlet A discovery of witches, which was designed to defended his witch-finding against the assize judges in Norfolk who called his techniques into question. Hopkins's text was first printed in Norwich in May 1647 and then printed in London in the same month. A discovery was printed by Richard Royston in Ivy Lane, and was intended to be sold at a shop in Norwich owned by Edward Martin. ${ }^{15}$ Following Hopkins's death, Stearne conducted one final hunt in the Isle of Ely, after which he retired and wrote his own retrospective work entitled, A confirmation and discovery of witchcraft (1648), which was printed by William Wilson, from 'Little Saint Bartholomewes neare Smithfield' in London. Like Hopkins, Stearne turned to print to clear his name and defend his actions against his detractors. In his text Stearne claimed that he had been labelled as a swindler, had been sued by two anonymous men in Colchester for his witch-finding, and therefore could not or would not return to his house in Essex. Stearne found this ironic as he was still awaiting payment for his witch-finding from many villages, which he threatened with further litigation. By publishing A confirmation, Stearne may have wanted to fix his version of the witch-hunt in print, and prove to his critics that he had operated within the law and according to Scripture - ultimately, he was not successful in the 


\section{Introduction}

latter. ${ }^{16}$ Despite the similarities between the two witch-finders, Stearne also highlighted the distance between himself and Hopkins in his text: Stearne seemed to be unaware of Hopkins's pamphlet that was published the previous year, believing, in 1648, that 'we never printed anything until now, ${ }^{17} \mathrm{~A}$ confirmation is evidently a valuable text, particularly since archival sources on Stearne's life are lacking. His pamphlet provides us with an insight into his mind, and the minds of those who confessed to witchcraft. Throughout A confirmation Stearne presents witches' confessions as irrefutable evidence for the existence of malefic witches, testimonies which he corroborated with biblical and historical precedents to convince his readers of the veracity of his conclusions.

This book is the first full-scale study of Stearne and his Confirmation. It provides an analysis of Stearne's pamphlet and demonstrates how the witch-finder's beliefs related to and interacted with other intellectual frameworks during the English Civil War. It is a micro-history which seeks to contextualise Stearne's work within the social and intellectual environment which produced it, reconstructing the readership for which it was produced, and its transmission in succeeding centuries. Stearne's pamphlet was not widely circulated in the 1640 s, and it remained unknown to most scholars until the twentieth century. This, coupled with a paucity of research focussing on Stearne, has resulted in misrepresentations of him in the historiography of witchcraft, which has portrayed him as Matthew Hopkins's assistant, a staunch puritan, and as an opportunist whose sole motivation for witch-hunting was monetary gain. ${ }^{18}$ Although Stearne has not been completely overlooked by historians, he is often overshadowed by his partner, Hopkins, whose role in the episode historians have exaggerated. This book will redress this imbalance and investigate the beliefs articulated by Stearne in A confirmation to enhance our understanding of the witch-hunter and his sole publication. While some of Stearne's ideas were analogous to mainstream seventeenth-century intellectual and puritan cultures, others deviated from these standards. The various ideas presented by Stearne in A confirmation do not correspond to those of a homogenous body of beliefs upheld by popular, learned or puritan cultures in East Anglia. This complicates attempts to use Stearne as a symbol for a larger group of people in south-east England or nationwide. Studies on Stearne and the driving forces behind the witch-hunt therefore need to be more nuanced and should view the trials in their local contexts. This book will provide an alternative reading to the traditional historiography relating to the East Anglian witch-hunt. In order to do so it will rely on a variety of primary and manuscript sources, and will also make use of the evidence and interpretive frameworks of English, Scottish, and European scholars. The following section will give a very broad overview of modern historiographical trends related to the study of English witchcraft, the East Anglian witch-hunt, and John Stearne to aid students and researchers unfamiliar with the topics. 


\section{Literature Review}

In the early twentieth century, Wallace Notestein, C. L. Ewen, and R. Trevor Davies published influential works on Stearne and Hopkins. ${ }^{19}$ Notestein's traced The history of witchcraft in England from 1558 to 1716 (1911), relying on a wealth of printed primary sources to provide a synopsis of the topic. According to Notestein's research, English witchcraft beliefs were not domestic but foreign in origin. Protestant members of Edward VI's court had been exiled to Geneva during Mary's reign, where they learned European demonology. Once Elizabeth ascended to the throne, the Marian exiles returned to England, bringing their European ideologies with them hence the passing of an act against witchcraft in $1563 .{ }^{20}$ The exiles were primarily concerned with conjurers, but ordinary people also became involved in prosecutions by identifying witches within their communities and demanding their punishment. ${ }^{21}$ These events formed the basis for English witch-hunting, which peaked under the reign of Elizabeth I and declined until the outbreak in the 1640 s. $^{22}$ Notestein claims that Stearne and Hopkins capitalised on the 'judicial anarchy' caused by the Civil War. While there was disruption to the assize courts, 'anarchy' is an exaggeration. ${ }^{23}$

In 1947, R. Trevor Davies attributed the East Anglian witch-hunt to an exogenous ideology by following Notestein's line of thought, producing the most convincing argument for the Marian exiles' role. ${ }^{24}$ Davies argued that the introduction of the persecution of witches gained its impetus from returning Protestant refugees who had been living in 'cities where the witch-burnings were taking place on a most extensive scale'. ${ }^{25}$ In Four centuries of witch-beliefs Davies cited sources to link the development of the English social elite's theories of witchcraft to those of Calvinist Europe, and suggested a top-down process through which witchcraft belief was disseminated to the lower orders in the form of 'sensational popular pamphlets'. ${ }^{26}$ When concentrating on the 'witch-mania' in East Anglia, Davies concluded that

the influence of the returned exiles was by no means the only cause of the growth of witch-belief. The south-east of England was at this time the most highly developed industrially and commercially. Consequently, economic as well as geographical reasons brought it into the closest communication with the Continent. ${ }^{27}$

He continued by claiming that Calvinism 'would be likely to spread most readily in an industrial and commercial community'. ${ }^{28}$ Davies argued that mercantile trading in East Anglia, with its close proximity and ideological links to the continent, made Calvinist doctrine likely to spread in its commercially orientated community; industrial areas attracted more European commerce and this increased the prevalence of continental witchcraft beliefs. ${ }^{29}$ According to Davies, by the seventeenth century the European 


\section{Introduction}

belief in demonic witches was widespread in England, and the prosecution of witches was only mitigated by Charles I, who suppressed witch-trials. Davies noted that by the outbreak of the Civil War, witchcraft belief had combined with anti-Catholic and anti-Royalist sentiments, literally demonising these groups in the minds of many puritans and supporters of Parliament. In this light, the witch-hunt undertaken by Hopkins (Stearne is mentioned twice in passing) in the puritan heartland of East Anglia was an attempt to eradicate the demonic influences of Royalist supporters, Catholics, and Laudians. Davies suggested that once puritans gained the upper hand in the Civil War, they began to systematically investigate those believed to be witches, after decades of repression. ${ }^{30}$

Both Davies and Notestein overstate their arguments, primarily because they suggest a top-down process that was applied by the social elite. This neglects the fact that witchcraft accusations operated at a village level and so came from 'below', rather than 'above'. Even in the East Anglian trials, locals accused their neighbours of maleficia, and if suspects were found guilty by Justices of the Peace they were hauled before the courts. ${ }^{31}$ This is how Matthew Hopkins and John Stearne found suspected witches: they were invited to villages and aided by locals in their search for witches. While some of Davies's arguments are valid, the impetus behind the East Anglian witch-trials cannot be solely attributed to puritanism, as Laudians and religious radicals engaged with witch-hunting at a local level. Puritans were also divided on their religious beliefs and on witch-hunting: some supported the practice, while others tried to suppress it. ${ }^{32}$ Indeed, Stearne's beliefs were not fully compatible with 'orthodox' puritanism (Chapter 2), and he therefore cannot be said to represent a group of East Anglian puritans intent on rooting out witches. Notestein and Davies's argument that seventeenth-century witchcraft trials are indicative of the Protestant exiles' imported European demonology is problematic when we consider the lack of the witches' sabbat and the prominence of familiar spirits in English witchcraft beliefs. Familiars were supernatural agents that, as a concept, were almost unique to England and they sat uneasily alongside 'orthodox' Protestant beliefs - they were heavily referenced in Stearne's pamphlet. ${ }^{33}$

More attention was paid to these native English traditions in C. L. Ewen's book, which suggested that English demonology gradually developed, with some influences from Europe, without being directly imported from the continent. ${ }^{34}$ Ewen, however, is better known for his outstanding archival work. For his first publication, Ewen collected and edited all the extant witchcraft indictments for the Home Circuit from 1559 to 1736 in $1929 .{ }^{35}$ This was soon followed by Witchcraft and demonianism (1933), which contained the depositions and confessions of indicted witches. ${ }^{36}$ Both of these publications relied heavily on Stearne's work when discussing the East Anglican witchcraft trials. Unfortunately Ewen's work did not gain much recognition during his lifetime. For modern researchers, though, his work is indispensable and scholars now regard it as 'pathbreaking. ${ }^{37}$ 
Other scholars did achieve notoriety for their flawed methodology and literal readings of primary texts. Margaret Murray, author of The witchcult in western Europe (1921), used English and Scottish sources to speculate that witches were members of a pre-Christian religion who worshiped a horned god. ${ }^{38}$ When these covens met to worship, a male leader impersonated their god and performed sexual rites with attendees. In this respect, Murray was influenced by the anthropologist George Frazer and his multivolume work, The golden bough (1890). ${ }^{39}$ Frazer's account of the ritual killing of a priest-king appealed to Murray, leading her to believe that the witch-coven's leader, or a substitute, would be sacrificed cyclically to ensure the fertility of their crops. ${ }^{40}$ Because the coven's god was horned, she argued, Christian theologians demonised and subsequently persecuted the 'witches' for their heterodox beliefs. But Murray expounded this to suggest that the 'chief female' of these congregations was the 'Elfin Queen', thus merging fairy and witchcraft beliefs. The fairy queen was not part of folklore; instead the figure emanated from the memory of real people - an ancient dwarf race of humans from northern and western Europe who sheltered in earth mounds. According to Murray, witches were identified with 'fairies' and were demonised by theologians. To Murray, this explained why fairy-lore featured in Scottish witchcraft trials: both were remnants of a pre-Christian religion and were still active in popular religion. ${ }^{41} \mathrm{Al}-$ though Murray was innovative in attempting to study the witch-hunts dispassionately, her work has been completely discredited by historians due to her unsubstantiated theories; however, the concept of an ancient pagan cult has found purchase with modern Wiccans, for whom it is of central importance. ${ }^{42}$ The scholar most effective at demolishing Murray's methodology was Norman Cohn in his seminal work, Europe's inner demons (1976). He applied 'historical criticisms' to The witch-cult and convincingly showed how Murray had manipulated the evidence by misquoting texts, which were taken out of context. In the same publication he demonstrated how the idea of demonic witchcraft emerged in the later middle ages out of pre-existing conceptions and concerns of magic and heretical sects - not from a pre-Christian fertility ritual. ${ }^{43}$

Montague Summers did not share Murray's sentiment of a wrongly persecuted cult, calling her work 'radically and wholly erroneous' because it suggested that the Dianic cult may have rivalled the Christian Church. ${ }^{44}$ When Summers wrote The history of witchcraft (1926) and The geography of witchcraft (1927), he had an explicit agenda: 'I have endeavoured to show the witch as she really was - an evil liver; a social pest and parasite; the devotee of an obscene creed'. ${ }^{45}$ To him, witchcraft was a not past threat but remained a very real one that still threatened to disrupt society in his time. ${ }^{46}$ His analysis did not gain much credence among scholars, most of whom he viewed with contempt. ${ }^{47}$ Both Murray and Summers treated witchcraft as a modern reality and sought to prove this using primary materials. This resulted in biased interpretations, as well as selective readings 


\section{Introduction}

of their sources. With regard to the East Anglian witch-hunters, Summers labelled Hopkins as a swindler whose primary concern was money, and only referred to Stearne when calling him 'Hopkins' satellite'. ${ }^{48}$ Likewise, Murray used Stearne's text as a source but said little of the author, except when calling him 'Hopkins's co-worker'. ${ }^{9}$ Murray used Stearne's Confirmation in her narrative about the witch Joane Wallis. Stearne recorded that Wallis confessed, 'the Devill came to her in the likenesse of a man, in blackilish cloathing, but had cloven feet'. ${ }^{50}$ Murray used this passage as evidence of 'the Devil's costume' - that is, how the leader of the witch-coven dressed in a black suit and cleft shoes when its members met. ${ }^{51}$ Despite its flaws, her interpretation of witchcraft gained popular acceptance, even appearing in the Encyclopaedia Britannica. Murray's argument was not seriously challenged until the 1970s by Norman Cohn, Alan Macfarlane, and Keith Thomas. ${ }^{52}$

In an attempt to understand and reinterpret John Stearne's world, Keith Thomas and his student Alan Macfarlane revolutionised English witchcraft studies by utilising social anthropology, based on E. E. Evans-Pritchard's findings in Witchcraft, oracles and magic among the Azande (1937). ${ }^{53}$ Macfarlane used legal records and printed pamphlets to study witchcraft in Essex, whereas Thomas used the same 'history-from-below' approach to investigate a variety of supernatural beliefs in early modern England. Macfarlane's work took the form of a micro-study while Thomas's focus was much wider in scope. ${ }^{54}$ Both historians linked witchcraft accusations to socio-economic tensions at the village level - this became known as the 'charity-refused-model'. In the refused-charity paradigm, those relying on charity may have acted aggressively and cursed an individual who refused to provide it. If, after a curse was muttered, something happened to the person who refused the beggar charity, they could be accused of maleficia (harmful magic). As the population increased and the richer members of society became commercially orientated, the gap between them and the poor widened, leading to increased interpersonal tensions. This clashed with ideals of charity and neighbourliness, which were fundamental aspects of everyday life either side of the Reformation. ${ }^{55}$ However, some members in English society may have already viewed local beggars and the vagrant poor with distain, regarding them as potential burdens to their community, therefore adding to their suspicion. The charity-refused-model theorises that individuals were torn between public (the poor law) and private charity, creating feelings of guilt. Apart from ascribing unexplainable misfortune to the witch, Thomas and Macfarlane suggested that accusations may also have been the manifestation of psychological guilt. Witchcraft accusations served to alleviate their guilty conscience by construing the beggar as a malefic witch. 56

By exploring this functionalist model of English witchcraft accusations, Thomas and Macfarlane highlighted the popular impetus behind trials and contested the paradigm of imposed European demonological thought. ${ }^{57}$ 
They also shed light on the cunning-folk of England, who operated as counter-witches, healers, and diviners for the public. For this, Macfarlane and Thomas took inspiration from Evans-Pritchard's anthropological study of the African Azande tribe. Evans-Pritchard separated African sorcerers from witches and magic (ngwa) from witchcraft (mangu). The Azande believed that witchcraft was everywhere; it was hereditary and part of daily life. In contrast, sorcery was voluntary, relying on spells and rituals. If witchcraft was suspected, the Azande tribe had a complicated system of oracles to consult, in order to locate witches and cure a bewitched individual. Macfarlane and Thomas applied this conceptual framework of counter-witchcraft to England to locate and examine cunning-folk, and to identify village social-strains present in the early modern period. One early English example similar to the Azande's methods of consultation and discovery can be found in the 'Witches of Warboys' case, in Huntingdonshire. From 1589 to 1595, the Throckmorton family's servants and children were stricken by bouts of illness, which were eventually attributed to witchcraft. Before witchcraft was diagnosed and prosecutions were brought against the Samuel family by the Throckmortons, the latter consulted two physicians (who prescribed medicine four times), two divines, neighbours, family members, and friends, including Lady Susan and Sir Henry Cromwell (Oliver Cromwell's grandfather). ${ }^{58}$ But a simple example directly related to this study involves John Rivet, who we encountered earlier. He suspected that Elizabeth Clarke had bewitched his wife and so he consulted a cunning-man who confirmed this: Stearne's help was then sought and the East Anglian witchcraft investigations were initiated.

Thomas's and Macfarlane's publications remain influential. To date, Macfarlane is the only scholar to have produced a regional study of witchcraft and magic beliefs in Essex. In the introduction to the second edition of Macfarlane's Witchcraft in Tudor and Stuart England (1999), the lack of historiography on this area led James Sharpe to remark that 'we need a new doctoral thesis on Essex witchcraft'. ${ }^{59}$ Despite being influential since publication, Macfarlane's and Thomas's theories are not without issue and cannot be used as blanket explanations for Europe as a whole or, more narrowly, the English witch-trials of the 1640s. As scholars applied their model to other countries (primarily in the 1990s), it appeared that England was not as idiosyncratic as its scholars had assumed; rather, it was like many other parts of Europe. It was discovered by researchers such as Robin Briggs that, like England, European witchcraft prosecutions were sporadic and were usually driven by the villagers, not by the ruling elite. ${ }^{60}$ As Briggs noted, stimulus from the higher orders or socio-economic tensions at a localised level were certainly factors, but they were a few explanations within a nexus of many. ${ }^{61}$ Nonetheless, Thomas and Macfarlane created a heightened awareness of the popular impulse behind English accusations and this led to further research into the beliefs underpinning them. Although Thomas regarded the witches' confessions of the 1640s as completely atypical because 
of Hopkins and his reading of European demonology, James Sharpe challenged this by re-examining the witchcraft beliefs presented in these trials. ${ }^{62}$ Sharpe argued that popular English witchcraft theory, although not as diabolic as its European counterpart, did contain demonic content (familiar spirits, sex with demons, the witch's mark and even hints of the witches' sabbat), therefore suggesting a blend between learned and popular beliefs (this has been recently reinforced by Charlotte-Rose Millar's work). ${ }^{63} \mathrm{~A}$ combination of these is evident in the mid-seventeenth century witch-trials, which John Stearne detailed in his pamphlet.

One constant between learned and popular beliefs in both England and mainland Europe was that the vast majority of witches were women. In $A$ confirmation Stearne recorded that it was 'evident' that 'of Witches in general, there be commonly more women then men' ${ }^{64}$ But this was not only evident to Stearne and his contemporaries. In the 1970s feminist historians turned their attention to the European witch-hunts and interpreted them as women-hunts. One of the most radical historians asserting this was Mary Daly, who viewed the European witch-craze as one of many historical episodes that clearly highlighted the brutal suppression and domination of females by the ruling male elite. ${ }^{65}$ Others, like Barbara Ehrenreich and Deirdre English in Witches, midwives and healers (1973), saw witch prosecutions as an attempt to root out female healers. According to Ehrenreich and English, women were persecuted as witches by the ruling elite in order to ensure a male monopoly on medical practice. Female healers were by no means ignorant of medicine nor did they solely rely on 'magic'; instead, their knowledge threatened to usurp their male counterparts. Ehrenreich and English claimed that 'it was witches who developed an extensive understanding of bones and muscles, herbs and drugs, while physicians were still deriving their prognoses from astrology' ${ }^{66}$ These are exaggerations and the alleged role of women healers is unfounded, as David Harley has shown, but the question of woman-hunting is more complex. ${ }^{67}$ As Clive Holmes has demonstrated, some witch-hunting may have been driven by misogyny, but in English witch trials women were directly involved in witch-finding, contributing to at least half of all witchcraft accusations by the early seventeenth century. ${ }^{68}$ Nonetheless, feminist historians in the 1970 s forced scholarship to consider the role of gender in witchcraft more seriously. Some of the earliest researchers to do so were E. William Monter and Jeffrey B. Russell. Monter recognised the preponderance of female witches, and concluded that 'misogyny was a basic force underlying these trials'. ${ }^{69}$ Working with earlier sources, Russell, like Monter, identified a connection between witchcraft, women, and subversive heretical groups. ${ }^{70}$ According to Monter, it was only in the fifteenth century, with the publishing of the Malleus Maleficarum, when witchcraft became an activity particularly identified with women. ${ }^{71}$

In a similar vein, Sigrid Brauner and Christina Larner noted links between state-building, heresy, and witchcraft. In 1995, Brauner attributed 
witch-hunting to the changing status of women, as defined 'by influential members of the early modern urban elite in Germany', before 'the great wave of witch-hunts' occurred in the $1560 \mathrm{~s}^{72}{ }^{2}$ Rather than examining German witchcraft trials per se, Brauner examined some well-known figures, including Heinrich Kramer and James Sprenger (authors of the Malleus Maleficarum), Martin Luther, and the plays of Paul Rebhun and Hans Sach. Based on these sources, Brauner's work asserted that the reformers' witch-hunting was designed to force adherence to Protestant, patriarchal views of marriage and society. While the Malleus linked witchcraft to female sexuality, Lutherans linked it to the concept of being a bad housewife a woman who failed submit to their husband's control, manage the household or represent moral virtue. ${ }^{73}$ Larner, on the other hand, maintained that Scottish governmental authorities took measures to eliminate witchcraft and heresy, both of which involved the prosecution of women. But Brauner's and Larner's interpretations are problematic in relation to England, since there was no state-led witch-hunt. Witchcraft prosecutions did rise in the early reign of James VI and I in Scotland but they declined markedly after his accession to the English throne. James VI and I even attempted to actively subdue witchcraft and investigated cases of suspected fraudulent bewitchment himself. ${ }^{74}$ Returning to the role of gender, Larner reached a conservative conclusion: witch-hunting was sex-related, not sex-specific. In this way, the attributes of a witch were sex-related because of the specificities of the witch-figure stereotype, but these characteristics could be, and were, applied to males a well. ${ }^{75}$ This interpretation is congruent with that of John Stearne, who, when speaking of witchcraft, remarked that 'one may fall into this sinne as well as into any other (if God prevent it not) and therefore whether men or women'.76

By the 1990s, historians were also developing another conceptual framework that concentrated on the emotions behind witchcraft accusations in an attempt to further our understanding. One such study was Lyndal Roper's, Oedipus and the devil (1994), which considered witch-hunting and gender. Roper's research focussed on early modern Germany, and used a psychoanalytical approach to investigate masculinity, femininity, and the body, in relation to the human psyche. Roper construed witchcraft accusations as projections of fear stemming from motherhood. Based on the sources studied, the victims of such accusations were mostly lying-in-maids. Maids lived with and were employed by families during the lying-in period to feed and care for the new-born child until the mother recovered. Roper argued that this led to ambiguity in the mother's role, which could result in anxiety and envy towards the maid. According to Roper, the mother became confused as to her role in the household while the maid stayed with the family to care for the child. During this period the infant was vulnerable and its mother was physically weak. Concerned with the potentially dangerous and envious old woman, the new mother projected her fears onto the maid. The maid was thus conceptualised as the antithesis of 


\section{Introduction}

motherhood and witchcraft accusations soon followed. ${ }^{77}$ In a similar line of thought to Roper, Deborah Willis highlighted that, in England, accusations arose from 'specific anxieties about maternal power (and related aspects of women's roles). ${ }^{78}$ Recently, John Durrant has modified these arguments to locate witchcraft accusations within a web of gender-based social networks, which interacted with the domestic sphere and ideals of a patriarchal society. ${ }^{79}$ Likewise, Diane Purkiss presented the witch-figure as an inversion of the mother-figure - early modern society conceptualised the witch-figure as the antithesis of the mother-figure, and as a polluted version of the female body. ${ }^{80}$ Another important finding by studies such as Roper's was the relationship between a suspect and an interrogator. She suggested that the witch was not simply fed information to create seemingly outlandish stories; rather 'the fantasy of witchhood was created in a project of collaboration between questioner and accused'. ${ }^{81}$ Roper's idea of witchcraft confessions forged through a reciprocal discourse is relevant to the practices employed by Stearne and Hopkins in the mid-seventeenth century - especially the concept of familiar spirits.

By focussing on gender, scholarship is now beginning to explore both male and female relationships to witchoraft trials and accusations. Male witches have recently been recognised and incorporated into the research of Lara Apps and Andrew Gow, Rolf Schulte, E. J. Kent, Alison Rowlands, and Brian Levack's collection of essays. ${ }^{82}$ Such studies are a reaction to the feminist historiography which downplayed the presence of male witches, who constituted an estimated $20-25 \%$ of those executed for witchcraft in Europe. Recent work has explored witch-trials in Normandy, Russia, Estonia, Iceland, and Finland, where the majority of witches were men. ${ }^{83}$ In sixteenth-century Finland, ' 60 per cent of those accused, and 75 per cent of those convicted for witchcraft were men'. ${ }^{84}$ And in some European witch-hunts like the 'Sorcerer Jack' trials of Salzburg (1678-80), where 140 people were tried and executed, men constituted $70 \%$ of all tried and executed witches. ${ }^{85}$ Although the male witch-figure is an alternative mode of analysis to the traditional historiography, it is still investigated under feminist theories. What constituted a male witch-figure and what led to men being accused of witchcraft has not yet reached a scholarly consensus. Lara App and Andrew Gow have argued, in Male witches in early modern Europe (2003), that a male witch was labelled as 'the other' in society, and was accused and conceptualised as a feminised man, for they were weakminded, like their female counterparts who also fell for Satan's deception. To App and Gow, early modern society failed to differentiate between male and female witches based on their sex; both male and female witches were imagined as being identical, and all witches were persecuted for having the feminine characteristic of weak-mindedness. ${ }^{86}$

The inflexibility of this theory is problematic when we examine the trials of the 1640s in relation to John Stearne's text. In the cases of John Bysack and John Scarfe, detailed in Stearne's pamphlet, the creation of an intimate 
blood covenant with Satan and allowing familiar spirits to feeding from their witch-marks, has led Malcolm Gaskill to perceive these acts as being homosexual. Bysack claimed that Satan's claw penetrated his jacket to obtain his heart's blood, and when Bysack's imps arrived at night, in the form of six snails, he would tell his wife he was uncomfortable, get up, and then settle by the fire to nurse his familiars. Scarfe, on the other hand, kept a rat in a box, which he would place on his stomach and allow it to feed from his witch-marks. This would support App and Gow's theory of a male witch being construed as a feminised man, and being accused of witchcraft. ${ }^{87}$ For Stearne, however, both male and female witches could be guilty of witchcraft, entertaining familiar spirits and making pact with Satan - two central pieces of pre-trial evidence in the East Anglia. It is even possible that Stearne and Hopkins primarily searched men for demonic marks, rather than women (Chapters 5 and 6) ${ }^{88}$ The crime of witcheraft was therefore not necessarily sex-specific to contemporaries, as Larner remarked. However strong the link between witchcraft and women seems to us, 'witchcraft constituted its own historical category' and consequently, male witches should be viewed as 'witches in their own right'. ${ }^{89}$

One final theme in recent scholarship that is central to Stearne's theorising of witchcraft is the prevalence of familiar spirits, which combines the previously covered subjects of popular beliefs, emotions, and gender. Although familiar spirits have been widely recognised by scholars, most have only noted their peculiarity. James Sharpe has remarked 'the familiar in early modern English witchcraft has not been given thorough analysis, although both trial records and pamphlets about trials contain a wealth of detail, sometimes contradictory, about them, ${ }^{90}$ To-date, only Emma Wilby has published a monograph on the topic. Building on previous scholars' work on witchcraft and its links to folklore - mainly that of Carlo Ginzburg, Gábor Klaniczay and Éva Pócs - Wilby's Cunning folk and familiar spirits (2005) discusses the shamanistic origins of the English familiar. ${ }^{91}$ Wilby draws comparisons between the familiar spirits of early modern cunning-folk and witches, and the descriptions of encounters with familiar spirits given by shamans from Siberia and Native America in the late nineteenth and early twentieth centuries, before the dominance of Christianity. To Wilby, the presence of the familiar spirit in the early modern and modern world is a clear indication that it is linked to a form of British, pre-Christian animism. Wilby seems to suggest a universal human belief in familiar-like creatures when she rules out the possibility of any transcultural transportation of beliefs from Europe to Siberia and America. In summary, she describes her premise as follows:

if an early modern familiar belief can be found to resemble a familiar belief found in a traditional non-European animist culture then this resemblance will be seen to support the likelihood that the former was rooted in pre-Christian British animism, that is, that it was of folkloric origin. ${ }^{92}$ 
In the early modern period this pre-Christian animism took the form of the 'fairy-faith' which, not Christianity, was the main religion for the vast majority of people. ${ }^{93}$ It was, moreover, fairy-lore that underpinned the whole construction of familiar spirit belief. ${ }^{94}$ Her emphasis on a widespread fairy belief as a 'faith' underpinning popular religious practices and magical beliefs is overstated, and is strikingly similar to Murray's ideas. ${ }^{95}$ Parallels between fairies and familiars are evident in some cases, and such comparisons can be helpful. Indeed other scholars suggest that beliefs in familiar spirits may have roots in traditional folklore, ceremonial magic, cunning-folk or learned demonology. Like Wilby, Diane Purkiss argued that the descriptions of familiars closely resembled those of the early modern fairy, specifically the household brownie. In early modern accounts, similarities between familiars and fairies range from their behaviour to their reliance on humans for food as a type of appeasement and an offering. ${ }^{96}$ James Sharpe, in Authority and consent in Tudor England (2002), suggested that familiars may have been folklorised versions of demons which learned magicians of the middle ages were supposed to have raised or drawn from cunning-folk who were believed to employ spirits to foretell the future, locate treasure, and heal sickly clients. ${ }^{97}$

Parallels between these supernatural creatures exist, but they are not so similar that familiars, fairies, and shamanistic spirits can be reduced to being the same supernatural entities. As Julian Goodare pointed out,

English familiars lived with their witches, whereas Scottish fairies lived elsewhere, in hills or other remote liminal spaces. English familiars also acted on behalf of their human owners, being sent out almost as doubles of the witch or representatives of their malice. This was surely the crucial feature of the familiar - and the fairy did not share it. ${ }^{98}$

Wilby's assessment of the shamanistic elements of English witchcraft has also been questioned in recent scholarship. Owen Davies's work has demonstrated that Siberian shamans used innate abilities and public rituals to transport themselves to the spirit world and interact with animal-like spirits. But in England, cunning-folk relied on books to contact supernatural entities and, in the majority of cases, if they saw spirits like familiars or fairies during their life it was by chance, not through rituals. Davies pointed out that when individuals claimed to be transported to fairyland, as far as we can tell, in the British Isles this was reported as happening corporeally rather than spiritually - while spiritual appearances were more common in Europe, in shaman-like tribes such as the benandanti. ${ }^{99}$ Similarities between shamans and practitioners of English low magic contacting supernatural spirits can be detected; however, due to their differences, Davies concluded that the term shaman 'loses its relevance in a European context'. ${ }^{100}$

This monograph will not draw comparisons between familiar spirits and shamans, but will be based on the contents of Stearne's Confirmation. It will treat familiar spirits as demons and narratives pertaining to them as parodies of social norms, following Stuart Clark's concept of inversion. 
This book will also incorporate the psychoanalytical approach taken by Lyndal Roper and Deborah Willis, who relate the feeding of familiars to bad motherhood, and Diane Purkiss, who proposed the concept of a polluted female body. ${ }^{101}$ Since blood was drawn from the witch's mark, which was often located near a witch's genitals, the sexual connotations of witchcraft will also be investigated. ${ }^{102}$ Rather than utilising Emma Wilby's interpretive framework, this book will consider familiar spirits as products of English demonology, for this was the context in which Stearne viewed them. ${ }^{103}$ Likewise, this monograph will engage in the scholarship surrounding witchcraft, sex, and gender, but the latter themes were not of critical concern to Stearne's witchcraft theory. In early modern English witchcraft prosecutions the bulk of witches identified within the Home Circuit, particularly in Essex, were women. ${ }^{104}$ Overall, an estimated 7\% were men, totalling around thirty individuals. ${ }^{105}$ Following the work of Rowlands, Durrant, and E. J. Kent, witchcraft will be treated as a social construct (the concept of a bad neighbour, masculinity, and femininity) that included fears, tensions, and deviancies from the religious, political, and domestic spheres of life. ${ }^{106}$ The early modern construction of the witch-figure cannot be solely attributed to sex or to male/female weakmindedness because it cut across and interlinked with gender-roles. The intellectualisation of witchcraft was more complex and far-reaching since it was an inversion of an entire culture. ${ }^{107}$ For this reason weakmindedness will be considered as a factor working alongside other possible explanations. The theories and methods discussed above will be used when analysing $A$ confirmation to draw out specific themes in each chapter and contextualise Stearne's ideas.

\section{Overview of Book}

John Stearne's biography and his only publication, A confirmation, have been not been sufficiently studied by scholars, most of whom have focussed on Hopkins and his Discovery of witches. To contextualise Stearne's work, the first chapter of this book presents an overview of the economy, courts, and the religious and political environment in which Stearne wrote $A$ confirmation, focussing on Essex and Suffolk, the two areas he resided in. This chapter provides background information on the community from which Hopkins and Stearne emerged, and the Presbyterian network which supported their witch-finding agenda. ${ }^{108}$ The second chapter continues with these themes to investigate Stearne's religious beliefs. Stearne has been labelled as being staunchly puritan by scholars, yet his articulation of religious belief has not been sufficiently investigated. Chapter 2 examines the applicability of this descriptor to the beliefs Stearne articulated in A confirmation and compares them to the 'orthodoxy' imposed by the Westminster Assembly. In order to situate Stearne's text in mid-seventeenth-century print cultures, Chapter 3 examines other contemporary pamphlets, many of which reported supernatural happenings inspired by the Civil War, while some directly relate to the East Anglian witch-trials. These sources are 
discussed in relation to the ideas found in A confirmation and how his text was constructed, disseminated, and received after publication. Chapter 4 concerns familiar spirits. These supernatural entities featured heavily in witches' confessions and in Stearne's Confirmation. This chapter explores early modern demonology and the development of the concept of familiars. Familiar spirits functioned as a symbol for a variety of medieval and early modern concerns over human-animal boundaries, morality, and sexuality, which influenced Stearne's ideas on familiars, both directly and indirectly. Stearne was able to prosecute witches effectively because he assimilated the ideas of previous demonologists pertaining to familiars and by using the 1604 Jacobean witchcraft act - which made owning familiars a felony - he extracted from suspects damning confessions of maleficia and ownership of familiars. The following chapter deals with the links between sex and gender in Stearne's witchcraft theory. In the early modern period, witches were predominantly represented as women, for they were believed to be the weaker sex and thus more prone to Satan's temptations. But Stearne noted that witches could be men or women, and he 'searched' and prosecuted both sexes, making little distinction. This chapter attempts to situate his ideas among his contemporaries' to explore seventeenth-century concepts of gender. Chapter 6 explores the scientific nature of Stearne's witch-finding. The chapter relates A confirmation to early modern scientific thought and examines how his 'searching' for witch-marks availed from seventeenthcentury empiricism. But the demonological theories that Stearne adopted incorporated natural philosophy, medicine, the law, and theology, and were contested throughout the early modern period. The emergent scientific community did not directly engage with Stearne's work; however, from the 1650 s to the early eighteenth century the witchcraft theories underpinning Stearne's witch-finding practices regained intellectual vitality and featured in the debates over the reality of the world of spirits. In the aftermath of these debates, the mid-1700s, witchcraft beliefs had declined in educated circles and it became impossible to prosecute and execute witches through the courts. However, scepticism did not hinder the transmission of Stearne's text in the following centuries for, as Chapter 7 demonstrates, antiquarians, ministers, and historians continued to collect $A$ confirmation for its rarity. Chapter 7 attempts to reconstruct the collection, ownership, and readership of all extant copies of Stearne's Confirmation from 1648 to modern day. Because his text was not widely disseminated in the 1640s, his text was unknown to scholars until the mid-1800s and, subsequently, did not enter historiography until the twentieth century. This has resulted in under- and misrepresentation of Stearne in scholarship. Still, Stearne's Confirmation has not been sufficiently studied by researchers. This book therefore seeks to enhance our understanding of Stearne and his text, both of which have been historically overshadowed by Hopkins and his pamphlet. Stearne's lengthier pamphlet provides more information on the witch-hunt than Hopkins', and is our primary means to investigate the witch-hunter's 
various beliefs and ideas. This study seeks to redress the historiographical imbalance by situating Stearne's text within its wider environment to enhance our understanding of one of the key actors in the East Anglian witchcraft trials (Figure I.1).

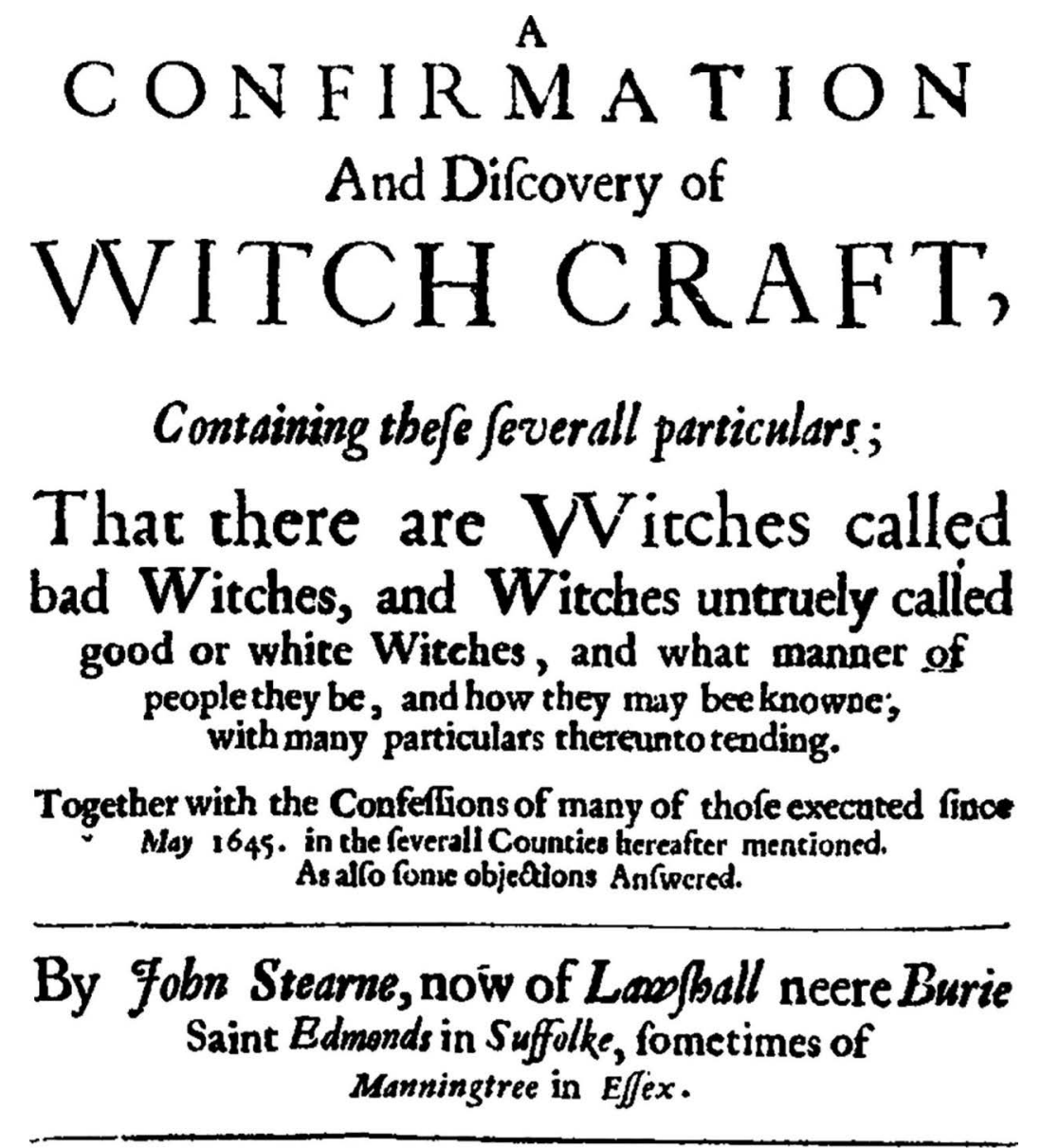

Prov.17.15. He tbal juftifietb tbe wicked, and be ibat condemnetb sbe juff, even ibey botb are an abomination to the Lord.

Devn 13. 14. Thou fhas therefore inquire, and make fearch, and aske diligentl, whe iber it be truth, and the thing certaine.

\section{LONDON,}

Printed by William Wilfon, dwelling in Little Saint Bartho! 0 . metres netre Simibfisti. $16+8-$

Figure I.1 John Stearne, A confirmation and discovery of witchcraft (London, 1648), Houghton Library, Harvard University, GEN 24244.74. 


\section{Notes}

1 Nathan Johnstone, The devil and demonism in early modern England (Cambridge, 2006), pp 75-6; for an overview see Darren Oldridge, The devil in early modern England (Stroud, 2004).

2 Jim Sharpe, 'The Devil in East Anglia: the Matthew Hopkins trials reconsidered' in, Jonathan Barry, Marianne Hester and Gareth Roberts (eds), Witchcraft in early modern Europe: studies in culture and belief (Cambridge, 1996), pp 237-8; James Sharpe, Witchcraft in early modern England (London, 2001), p 71. Though, John Stearne's, A confirmation and discovery of witchcraft (London, 1648), p 11, suggests a much higher figure of over 200 executions.

3 Bod. Rawl., B.393, f. 384v; WSRO, IC 500/2/65/9; WSRO, FL 600/4/12; ESRO, B105/2/3, ff. 30v, 38v, 39, 45v, 89; ESRO, B105/2/4, f. 29; PRO, E/179/246/20; PRO, E/134/2/Chas2/Mich5; PRO, SP24/10, ff. 102v-3r, 159r; PRO, SP24/78; PRO, PROB11/307; ERO, Q/RT41/526. For a facsimile of a handwritten deposition by Stearne, in which he details a discovery of witchmarks see Malcolm Gaskill, Witchfinders: a seventeenth century tragedy (London, 2005), pp 261-2; for the manuscript see the Ely Diocesan Records at Cambridge University Library, EDR, E12 1647/21. For transcribed legal documents pertaining to Stearne and the witch-hunt see C. L' Estrange Ewen, Witch hunting and witch trials (London, 1929); C. L' Estrange Ewen, Witchcraft and demonianism (London, 1933).

4 Bod. Rawl., B.393, f. 384v; CUL, VCCt.III 38, 1; PRO, PROB11/307/45; Rev. G.H. Dashwood (ed.), The visitation of Norfolk in the year 1563 (Norwich, 1878), i, pp 25-7, 448; Brig-General Bulwer (ed.), The visitation of Norfolk in the year 1563 (Norwich, 1895), ii, pp 254-5.

5 WSRO, FL600/4/1-2; WSRO, IC500/1/122/13; WSRO, IC500/2/65/9; PRO, E/179/246/20; PRO, E/134/2/Chas2/Mich5; Gaskill, Witchfinders, pp 38-9, 270. When I contacted the record offices in Essex and Suffolk in 2016 to enquire about John Stearne I was informed by archivists that the county archives held no material outside of those cited here.

6 For his puritanism see Gaskill, Witchfinders, p 38; Ivan Bunn and Gilbert Geis, A trial of witches: a seventeenth century witchcraft prosecution (London, 1997), p 142; Wallace Notestein, A history of witchcraft in England from 1558-1718 (Washington, 1911), p 166; Robin Briggs, Witches \& neighbours: the social and cultural context of European witchcraft (London, 1996), p 53. For Stearne's social status see Jim Sharpe, 'Stearne, John (D. 1671)' in, Richard Golden (ed.), Encyclopaedia of witchcraft: the western tradition (4 vols, Santa Barbara, 2006), iv, p 1084; Malcolm Gaskill, 'Fear made flesh: the English witch-panic of 1645-7' in, Claire Walker and David Lemmings (eds), Moral panics and the media in early modern England (Basingstoke, 2009), p 82; for Stearne's involvement in legal trials before the witch-hunt see ERO, Q/SR 320/59; for the 1650s see PRO, SP24/10, ff. 102v-3r, 159r; PRO, SP24/78; Peter Elmer, Witchcraft, witch-hunting and politics in early modern England (Oxford, 2016), p 126; Gaskill, Witchfinders, pp 275-6.

7 Cabeck held rectorship from 1614 to his death in 1665, after which it is unknown where Stearne went for work; see NRO, DN/SUB/2/1; NRO, DN/INV 51A/52; NRO, NCC will register Stockdell 19, MF/RO 237/4; S.H.A.H. (ed.), Bury St. Edmunds. St. James parish registers: marriages, 1562-1800 (Woodbridge, 1916), xvii, p 57.

8 Gaskill, 'Fear made flesh', p 83; Gaskill, Witchfinders, p 41; ERO, T/A 418/127/10; ERO, T/A 418/127/11; ERO, ASS 35/83/1/10; ERO, ASS 35/86/1/11; H. F., A true and exact relation (London, 1645), p 1; Matthew 
Hopkins, The discovery of witches (London, 1647), Querie 4; Stearne, A confirmation, pp 14-5; Frances Timbers, 'Witches sect or prayer meeting?: Matthew Hopkins revisited', Women's History Review, xvii, no. 1 (2008), pp 27-8.

9 R. Trevor Davies, Four centuries of witchcraft belief: with special reference to the Great Rebellion (London, 1947), pp 126-8; Malcolm Gaskill, 'The Matthew Hopkins trials' in, James Sharpe and Richard Golden (eds), English witchcraft, 1560-1736 (6 vols, London, 2003), iii, pp 331, 489-94; ERO, T/A 418/127/96-7.

10 Keith Thomas, Religion and the decline of magic: studies in popular beliefs in sixteenth-and seventeenth-century England (New York, 1985), p 545.

11 See, for example, Clive Holmes, 'Women: witnesses and witches', Past \& Present, cxl (Aug., 1993), pp 45-78.

12 Malcolm Gaskill, 'The Matthew Hopkins trials', iii, p xiv; Gaskill, Witchfinders, $\mathrm{p} 41$.

13 Gaskill, Witchfinders, p 80; Malcolm Gaskill, 'The Matthew Hopkins trials', iii, p 494.

14 ERO, D/P 343/1/1.

15 For dating of Hopkins's death see John Deacon, Matthew Hopkins: Witch Finder General (London, 1976), pp 193-6; Gaskill, 'The Matthew Hopkins trials', iii, p 495; Stearne, A confirmation, p 61. For the printing of Hopkins's pamphlet see Malcolm Gaskill, 'The Matthew Hopkins trials', iii, pp 317-8, 485.

16 Gaskill, 'Fear made flesh', p 86; S. F. Davies, The discovery of witches and witchcraft: the writings of the witchfinders (Brighton, 2007), p xiv; Stearne, A confirmation, sig. A1, pp 58-60; cf, Hopkins, Discovery, Querie 14. Stearne's, A confirmation and discovery of witchcraft will hereafter be referred to as $A$ confirmation or Stearne's Confirmation in the main text, and as Stearne, in notes.

17 Stearne, p 23.

18 Gaskill, Witchfinders, p 38; Bunn and Geis, A trial of witches, p 142; Notestein, A history of witchcraft, pp 164-6, 201; James Sharpe, Instruments of darkness: witchcraft in early modern England (Philadelphia, 1997), pp 140-1; Montague Summers, The history of witchcraft and demonology (London, 1926), pp 4, 102; Elmer, Witchcraft, witch-bunting and politics, p 126; Gaskill, 'The Matthew Hopkins trials', iii, p 331; Deacon, Matthew Hopkins, pp 66-7.

19 Notestein, A history of witchcraft; Ewen, Witch bunting and witch trials; Ewen, Witchcraft and demonianism; R. Trevor Davies, Four centuries of witch-beliefs.

20 For brief biographies of 800 known Marian exiles see Christina Garrett, Marian exiles: a study in the origins of Elizabethan Puritanism (Cambridge, 1938).

21 Notestein, A history of witchcraft, pp 14-28.

22 Ibid., pp 93, 105, 110, 120.

23 Ibid., pp 164, 201.

24 Davies, Four centuries of witchcraft belief, pp 2-57.

25 Ibid., p 15.

26 Davies attributes this influx of pamphlets to the Calvinist, George Abbot. An act of the Star Chamber gave Abbot, the Bishop of London (1609-33) and Archbishop of Canterbury (1611-33), control of the printing press. See Davies, Four centuries of witchcraft belief, p 43, and, Kenneth Fincham, 'Abbot, George (1562-1633)', Oxford Dictionary of National Biography (Oxford, 2004) (Available at doi:10.1093/ref:odnb/4) (Accessed: Dec., 2015). Oxford Dictionary of National Biography referenced in abbreviated form as ODNB hereafter. 
27 Davies, Four centuries of witchcraft belief, p 19.

28 Ibid.

29 Its 'industrial' nature is questionable considering its modern connotations, especially in a period when farming was still predominant; for example, see Joan Thirsk, The rural economy of England: collected essays (London, 1984).

30 Davies, Four centuries of witchcraft belief, pp 147-61.

31 Thomas, Religion and the decline, p 545; Holmes, 'Women: witnesses and witches', pp 45-78.

32 These divisions can be illustrated in Colchester, in 1645, where Stearne and Hopkins were invited by the Laudian mayor and supported by a group of moderate puritans. But Stearne and Hopkins were quickly expelled by another group of puritans who were supported by radicals: on this see Elmer, Witchcraft, witch-hunting and politics, pp 131-2.

33 Thomas, Religion and the decline, pp 595-8; Sharpe, Instruments of darkness, pp 130-1.

34 Ewen, Witchcraft and demonianism, pp 44-7.

35 Ewen, Witch hunting and witch trials.

36 Ewen, Witchcraft and demonianism.

37 Sharpe, Witchcraft in early modern England, p 11.

38 Margaret Murray, The witch-cult in western Europe: a study in anthropology (London, 1921). Besides Murray's work on this, the French writer Jules Michelet also purported this view. He maintained that the witches' sabbat was a nocturnal, canivalesque meeting of rebellious peasantry, during which they danced, feasted and performed fertility rituals. For the English translation see Jules Michelet, La sorcière: the witch of the middle age, trans. L. J. Trotter (London, 1863), pp 143-56.

39 Sir James Frazer, The golden bough: a study in magic and religion (abridged edn, London, 1950).

40 In the 1950s Murray expanded her theory of ritual sacrifices to the 'Old Religion' to include English royalty and prominent political figures; see Ronald Hutton, The pagan regions of the ancient British Isles: their nature and legacy (Oxford, 1998), pp 303-6, and pp 284-341 for a critique.

41 Murray, The witch-cult, p 14; Jacqueline Wilson, 'Murray, Margaret Alice (1863-1963)' in, Golden (ed.), Encyclopaedia of witchcraft, iii, pp 796-7; A. D. J. Macfarlane, 'Murray's theory: exposition and comment' in, Max Marwick (ed.), Witchcraft and sorcery (Middlesex, 1970), pp 201-3. For fairy beliefs in Scottish witch-trials see Julian Goodare, Lauren Martin and Joyce Miller (eds), Witchcraft and belief in early modern Scotland (Basingstoke, 2008).

42 For an account of contemporary Wiccan and pagan practices see Ronald Hutton, The triumph of the moon: a history of modern pagan witchcraft (Oxford, 1999); also see John Callow, Embracing the darkness: a cultural history of witchcraft (London, 2018).

43 Norman Cohn, Europe's inner demons: the demonization of Christians in medieval Christendom (2nd edn, London, 1993), pp 155-160, 200-10.

44 Summers, The history of witchcraft and demonology, p 32, see pp 31-45 for the debate in its entirety.

45 Montague Summers, The geography of witchcraft (London, 1927); quotation from Summers, The history of witchcraft and demonology, $\mathrm{p}$ xiv

46 Summers, The history of witchcraft and demonology, p 32.

47 For a contemporary review see George Lincoln Burr, 'Review of The history of witchcraft and demonology; Geography of witchcraft; Malleus Maleficarum; Demoniality', The American Historical Review, xxxiv, no. 2 (Jan., 1929), p 321.

48 Summers, The history of witchcraft and demonology, pp 4, 102.

49 Murray, The witch-cult, p 214. 
50 Stearne, p 13.

51 Murray, The witch-cult, pp 31-4.

52 R. S. Simpson, 'Murray, Margaret Alice (1863-1963)', ODNB (Oxford, 2004) (Available at: doi:10.1093/ref:odnb/35169) (Accessed: Dec., 2019).

53 Thomas, Religion and the decline (London, 1971), pp 675-6; Alan Macfarlane, Witchcraft in Tudor and Stuart England: a regional and comparative study (London, 1970, 2nd edn, 2008); E. E. Evans-Pritchard, Witchcraft, oracles and magic among the Azande (London, 1937).

54 For criticisms see E. P. Thompson, 'Anthropology and the discipline of historical contexts', Midland history, i, no. 3 (1972), pp 41-55; and, Hildred Geertz, 'An anthropology of religion and magic, I', Journal of Interdisciplinary History, vi, no. 1 (Summer, 1975), pp 71-89.

55 Peter Marshall, Reformation England, 1480-1642 (New York, 2nd edn, 2012), pp 155, 159-60, 207; Christopher Marsh, Popular religion in sixteenth century England: holding their peace (Basingstoke, 1998).

56 Thomas, Religion and the decline, pp 554-7, 673-8. Macfarlane, Witchcraft, p 196.

57 For example see Thomas, Religion and the decline, pp 595-7.

58 Thomas, Religion and the decline, pp 551-4; Anon., The most strange and admirable discouerie of the three witches of Warboys (London, 1593). James Sharpe, 'Warboys, Witches of (1593)' in, Golden (ed.), Encyclopaedia of witchcraft, iv, pp 1179-80. For a list of all the actors see Philip C. Almond, The Witches of Warboys: an extraordinary story of sorcery, sadism and satanic possession (London, 2008), pp xv-xvi.

59 James Sharpe, 'Introduction' in, Macfarlane, Witchcraft (2nd edn, 1999), $\mathrm{p} \times \mathrm{xx}$.

60 In Christina Larner's Enemies of God: the witch-hunt in Scotland (London, 1981) and Witchcraft and religion: the politics of popular belief (Oxford, 1984), she provides evidence to suggest that Scottish witch-hunts were stimulated from above.

61 For an in-depth discussion see Briggs, Witches \& neighbours, passim, especially pp 140-6, which situates the Macfarlane-Thomas model with Briggs's analysis of Europe.

62 Thomas, Religion and the decline, pp 530-3.

63 James Sharpe, 'In search of the English sabbat: popular conceptions of witches' meetings in early modern England', Journal of Early Modern Studies, ii (2013), pp 161-83; Sharpe, Instruments of darkness, pp 70-79; Sharpe, 'The Devil in East Anglia', pp 244-50; Sharpe, 'Familiars' in, Golden (ed.), Encyclopaedia of witchcraft: the western tradition, ii, pp 347-8; Charlotte-Rose Millar, Witchcraft, the devil, and emotions in early modern England (London, 2017).

64 Stearne, p 10.

65 Mary Daly, Gyn/ecology: the metaethics of radical feminism (Boston, 1978), pp 178-222.

66 Barbara Ehrenreich and Deirdre English, Witches, midwives and healers: a history of women healers (New York, 1973, 2010), passim, quotation from p 53.

67 See David Harley, 'Historians as demonologists: the myth of the midwife-witch', The Society for the Social History of Medicine, iii, no. 1 (1990), pp 1-26.

68 Holmes, 'Women: witnesses and witches', pp 45-78.

69 E. William Monter, Witchcraft in France and Switzerland (London, 1976), p 141.

70 Jeffery B. Russell, Witchcraft in the middle ages (London, 1972), pp 279-84. For a discussion of women's place in European society and religion during this period see, Natalie Zemon Davis, Society and culture in early modern France (Stanford, 1975). 


\section{Introduction}

71 Monter, Witchcraft in France, pp 23-7.

72 Sigrid Brauner, Fearless wives and frightened shrews: the construction of the witch in early modern Germany (Amherst, 1996), pp 113, 118.

73 Ibid., p 116.

74 James Sharpe, The bewitching on Anne Gunter: a horrible and true story of football, witchcraft, murder and the King of England (London, 1999), pp 169-96.

75 Larner, Enemies of God, pp 92, 100.

76 Stearne, p 12.

77 Lyndal Roper, Oedipus and the devil: witchcraft, sexuality and religion in early modern Europe (London and New York, 1994, reprinted 2005), pp 200-27.

78 Deborah Willis, Malevolent nurture: witch-hunting and maternal power in early modern England (Ithaca, 1995), p 244.

79 Johnathan Durrant, Witchcraft, gender and society in early modern Germany (Leiden, 2009), pp 197-8, 251-4.

80 Diane Purkiss, The witch in history: early modern and twentieth-century representations (London, 1996, reprinted 2005).

81 Ibid., pp 229, 242.

82 Lara Apps and Andrew Gow, Male witches in early modern Europe (New York, 2003); Rolf Schulte, Man as a witch: male witches in Central Europe (Basingstoke, 2009); E. J. Kent, 'Masculinity and male witches in Old and New England, 1593-1680', History Workshop Journal, lx, no. 1 (Autumn, 2005), pp 69-92; Alison Rowlands (ed.), Witchcraft and masculinities in early modern Europe (Basingstoke, 2009); Brian Levack (ed.), New perspectives on witchcraft, magic and demonology: gender and witchcraft (6 vols, London, 2001), iv.

83 Apps and Gow, Male witches, p 2.

84 Rowlands (ed.), Witchcraft and masculinities, pp 5-6.

85 Thomas Robisheaux, 'The German witch trials' in, Brian Levack (ed.), The Oxford handbook of witchcraft in early modern Europe and colonial America (Oxford, 2013), p 185; Schulte, Man as a witch, p 232.

86 For an overview of this historiography see, Katharine Hodgkin, 'Gender, mind and body: feminism and psychoanalysis' in, Johnathan Barry and Owen Davies (eds), Palgrave advances in witchcraft historiography (Basingstoke, 2007), pp 194-6.

87 Malcolm Gaskill, 'Masculinity and witchcraft in seventeenth-century England' in, Rowlands (ed.), Witchcraft and masculinities, pp 177-8; Stearne, pp 41-2.

88 Marion Gibson, Rediscovering renaissance witchcraft (New York, 2018), p 19; Holmes, 'Women: witnesses and witches', p 71; Stearne, pp 14-25; Hopkins, Discovery; EDR, E12 1647/21; Ewen, Witch hunting and witch trials, pp 223-8, 230-1, 292, 294, 300, 313; Gaskill, Witchfinders, pp 232-3, 251, 254-5, 261-2.

89 Gaskill, 'Masculinity and witchcraft', pp 173, 180. Callow, Embracing the darkness, $\mathrm{p} 18$, suggests using the concept of a 'familial noun' when thinking of the witch-figure, whereby accused witches bear traits that resemble an ideal witch-archetype.

90 Sharpe, 'Familiars', p 347. Also see, Sharpe, Witchcraft in early modern England, pp 62-4; and, Sharpe, Instruments of darkness, pp 70-2.

91 Emma Wilby, Cunning folk and familiar spirits: shamanistic visionary traditions in early modern British witchcraft and magic (Brighton, 2005); also see, Wilby, 'The witch's familiar and the fairy in early modern England and Scotland', Folklore, cxi, no. 2 (Oct., 2000), pp 283-305; Carlo Ginzburg, The 
night battles: witchcraft and agrarian cults in the sixteenth and seventeenth centuries (Baltimore, 1983); Éva Pócs, Between the living and the dead: a perspective on witches and seers in the early modern age (Budapest, 1999); Gábor Klaniczay, The uses of supernatural power: the transformation of popular religion in medieval and early-modern Europe (Cambridge, 1990).

92 Wilby, Cunning folk, p 126.

93 Ibid., pp 14-25.

94 Wilby, 'The witch's familiar', p 283.

95 Ibid., p 24, and Murray, The witch-cult, p 14.

96 Diane Purkiss, 'Fairies' in, Golden (ed.), Encyclopaedia of witchcraft, ii, pp 345-6.

97 James Sharpe, 'The witches' familiar in Elizabethan Essex' in, G. W. Bernard and S. J. Gunn (eds), Authority and consent in Tudor England (Aldershot, 2002), pp 219-32. These concepts are reiterated in, Sharpe, 'Familiars', pp 347-9. Millar's work on witchcraft pamphlets also treats familiars as demonic entities and applies a psychoanalytical approach to these narratives; see, Millar, Witchcraft, the devil, and emotions.

98 Julian Goodare, 'Scottish witchcraft in its European context' in, Julian Goodare, Lauren Martin and Joyce Miller (eds), Witchcraft and belief, pp 36-8; also see, Victoria Carr, 'The witch's animal familiars in early modern southern England' (PhD thesis, University of Bristol, 2017), pp 98-103.

99 Owen Davies, Popular magic: cunning-folk in English history (London, 2003), pp 177-86; see Ginzburg, The night battles.

100 Davies, Popular magic, p 18.

101 Willis, Malevolent nurture, pp 52-9.

102 For its sexual element see Charlotte-Rose Millar, 'Sleeping with devils: the sexual witch in seventeenth-century England' in, Marcus Harmes and Victoria Bladen (eds), Supernatural and secular power in early modern England (Farnham, 2015), pp 207-31.

103 For a similar approach see Oldridge, The devil, pp 137-141; and, Fredrick Valletta, Witchcraft, magic and superstition in England, 1640-70 (Farnham, 2000).

104 Sharpe, Instruments of darkness, p 131.

105 Gaskill, 'Masculinity and witchcraft', p 175; Macfarlane, Witchcraft (1999), $\mathrm{p}$ xix.

106 E. J. Kent, Cases of male witchcraft in Old and New England, 1592-1692 (Turnhout, 2013), pp 159-66. On this also see Durrant, Witchcraft, gender and society, pp 197-8, 251-4.

107 Alison Rowlands (ed.), "Not "the usual suspects"? Male witches, witchcraft and masculinities in early modern Europe' in, Rowlands (ed.), Witchcraft and masculinities, pp 18-9; Durrant, Witchcraft, gender and society, pp 249-54; Stuart Clark, Thinking with demons: the idea of witchcraft in early modern Europe (Oxford, 1999), passim.

108 Gaskill, Witchfinders, pp 37-8.

1 Stearne, p 20; Davies, The discovery of witches, p 56.

2 Elmer, Witchcraft, witch-hunting and politics, pp 131-8.

3 Clive Holmes, The Eastern Association in the English civil war (New York, 1974), pp 33-68.

4 Gaskill, Witchfinders, p 118. For a contemporary example, on 8 July 1645 , Parliament attempted to levy 500 men in Suffolk and execute all those who deserted; see Robert Ashton, 'From Cavalier to Roundhead tyranny, 1642-9' in, John Morrill (ed.), Reactions to the English civil war 1642-1649 (London, 1982), p 188.

5 Diane Purkiss, The English civil war: a people's history (London, 2007), pp 534-7.

6 ERO, Q/SR 326/1-10. 
7 Cited and explained in Alan MacFarlane, The family life of Ralph Josselin a seventeenth-century clergyman: an essay in historical anthropology (London, 1970), pp 71-4.

8 Ibid., pp 75-6; The diary of Rev. Ralph Josselin, 1616-1683, ed. E. Hockliffe (London, 1908), pp 16, 34; A. G. E. Jones, 'Plagues in Suffolk in the seventeenth century', Notes \& Queries, cxcviii (Sept., 1953), pp 384-6.

9 J. A. Goldstone, 'The demographic revolution in England: a re-examination', Population Studies, xl, no. 1, (March, 1986), pp 5-33; W. G. Hoskins, 'Harvest fluctuations and English economic history, 1620-1759', Agricultural History Review, xvi (1968), pp 15-31.

10 Michael Chisholm, 'Navigation and the seventeenth-century draining of the Fens', Journal of Historical Geography, xxxii, no. 4 (Oct., 2006), pp 733-40.

11 Purkiss, The English civil war, p 280.

12 Deacon, Matthew Hopkins, p 65; Donald Pennington, 'The war and the people' in, Morrill (ed.), Reactions, p 130.

13 ERO, Q/SBa 2/45-6; ERO, D/DMs O32; ERO, T/A 391/8, pp 3-6; ERO, D/ $\mathrm{DBa} / \mathrm{O} 19$; ERO, Q/SBc 2/25-6; John Morrill (ed.), 'Introduction' in Reactions, p 22; Pennington, 'The war and the people', idem, pp 128-9.

14 Sharpe, 'Stearne, John (D. 1671)' in, Golden (ed.), Encyclopaedia of witchcraft, iii, p 1085; Gaskill, Witchfinders, pp 275-6; Stearne, pp 58, 60.

15 Stearne, p 27; for examples of bewitched livestock during the 1640s see Ewen, Witch hunting and witch trials, pp 225, 229, 232; and Ewen, Witchcraft and demonianism, pp 268-9, 277.

16 Ewen, Witchcraft and demonianism, passim; Thomas, Religion and the decline, pp 3-4, 519, 774-7; Sharpe, Instruments of darkness, pp 59-62.

17 PRO, E/179/246/20; PRO, E/134/2/Chas2/Mich5; Elmer, Witchcraft, witchbunting and politics, p 126; Gaskill, 'The Matthew Hopkins trials', p 331; also see, Deacon, Matthew Hopkins, pp 66-7, who considers monetary gain to be Stearne and Hopkins's motivation for witch-hunting. Stearne, p 60, refuted these allegation stating:

And as for taking any money, or other things, by way of bribe or gift, I never did, to the value of one penny, neither one way nor other, but what I openly took in the view of the Townsmen where I came.

18 PRO, SP24/10, ff. 102v-3r, 159r; PRO, SP24/78; PRO, PROB11/307/45; Gaskill, Witchfinders, pp 275-6; Gaskill, 'The Matthew Hopkins trials', iii, pp 331, 488; Sharpe, 'Stearne, John (D. 1671)' in, Golden (ed.), Encyclopaedia of witchcraft, iii, p 1085; Stearne, pp 58, 60; Elmer, Witchcraft, witch-bunting and politics, p 126.

19 Eric Schneider, 'Real wages and the family: adjusting real wages to changing demography in pre-modern England', Explorations in Economic History, 1, no. 1 (Jan., 2013), pp 99-115; Holmes, The Eastern Association, pp 7-10; Patrick Wallis, Justin Colson, and David Chilosi, 'Structural change and economic growth in the British economy before the Industrial Revolution, 1500-1800', Journal of Economic History, lxxviii, no. 3 (2018), pp 862-903; Janet Cooper and C.R. Elrington (eds), A history of the county of Essex: volume 9, the borough of Colchester (10 vols, London, 1994), ix, pp 67-87.

20 Anon., The clothiers petition... of Suffolke, and the townes of Dedham and Langham in Essex (London, 1642).

21 Thirsk, The rural economy of England, pp 199, 209-10.

22 Deacon, Matthew Hopkins, pp 19-20; Gaskill, Witchfinders, p 27; Gaskill, 'The Matthew Hopkins trials', iii, p xiv. 
23 J. A. Sharpe, Crime in seventeenth-century England: a county study (Cambridge, 1983), pp 15-9; Deacon, Matthew Hopkins, pp 59-60; Holmes, The Eastern Association, pp 7-10.

24 ERO, T/Z 597/1; Holmes, The Eastern Association, p 7; John Walter, Understanding popular violence in the English Revolution: the Colchester plunderers (Cambridge, 1999), pp 64-8.

25 Sharpe, Crime in seventeenth-century England, p 25; Gregory Durston, Witchcraft $\&$ witch trials: a history of English witchcraft and its legal perspectives, 1542 to 1736 (Chichester, 2000), pp 191-8.

26 For an example of a JPs manual from the 1640s which contains excerpts from and annotations of printed legal texts (including Dalton's Countrey justice) see Folger Shakespeare Library, 'Legal notebook of Thomas Birch [manuscript]', V.a.395.

27 Durston, Witchcraft \& witch trials, pp 189-92.

28 C. L'Estrange Ewen, Witch hunting and witch trials (London, 1929), p 46.

29 Durston, Witchcraft \& witch trials, pp 186-7; G.R. Quaife, Godly zeal and furious rage: the witch in early modern Europe (Kent, 1987), pp 42-3; Macfarlane, Witchcraft, pp 120, 187; Thomas, Religion and the decline, pp 292-4, 551.

30 Marsh, Popular religion, p 110; Sharpe, Instruments of darkness, p 120; J. S. Purvis, Tudor parish documents of the diocese of York (Cambridge, 1948), $\mathrm{p}$ 1. For example, John Betson was given public penance for practicing divination (an act that came under the umbrella term 'witchcraft' for contemporaries) in 1563, while William Maykins was given the same punishment for suffering 'certain persons to drinke in his house [during] service tyme'; see Purvis, Tudor parish, pp 54, 198.

31 G.R. Quaife, Wanton wenches and wayward wives: peasants and illicit sex in early seventeenth century England (London, 1979), pp 18-9.

32 Anthony Fletcher, 'The coming of war' in, Morrill (ed.), Reactions, pp 44-5.

33 ERO, T/A 418/127/97; John Walter, 'The impact on society: a world turned upside down?' in, John Morrill (ed.), The impact of the English Civil War (London, 1991), p 112; Gaskill, 'Fear made flesh', p 83; Davies, Four centuries of witch-beliefs, pp 126-8.

34 Gaskill, Witchfinders, pp 158-9; Anon., A true relation of the araignment of eighteene witches (London, 1645).

35 Stearne, p 20.

36 Ibid., p 55; Sharpe, Crime in seventeenth-century England, pp 32-3.

37 ERO, T/A 418/127/98; Gaskill, Witchfinders, p 55; Ewen, Witch hunting and witch trials, pp 222-3. Sharpe, Crime in seventeenth-century England, p 32, estimates that 100 prisoners died of gaol fever between 1620 and 1650 .

38 William Perkins, A discourse of the damned art (Cambridge, 1610), pp 22-4.

39 Ibid., pp 27, 30-1; Alexandra Walsham, Providence in early modern England (Oxford, 1999), pp 84-224.

40 H.C. Erik Midelfort, Witch hunting in southwestern Germany, 1562-1684 (Stanford, 1972), p 11; Oldridge, The devil, pp 81-3. For a contemporary account of demonic possession see, John Darrell, A true narration of the strange and grevous vexation by the Devil (London, 1600). For familiar spirits see, Stearne, passim.

41 Robin Briggs, "By the strength of fancie”: witchcraft and the early modern imagination', Folklore, cxv, no. 3 (2004), p 268.

42 Thomas, Religion and the decline, pp 33, 42, 83, 590-3; Perkins, A discourse of the damned art, pp 229-31; George Gifford, A dialogue concerning witches and witchcrafts (London, 1593), sigs D4v, F3v.

43 On the devil-figure and the Reformation see: Marsh, Popular religion, pp 153-4; Oldridge, The devil, pp 58-68; Patrick Collinson, 'England' in, Bob 
Scribner, Roy Porter and Mikulas Teich (eds), The Reformation in a national context (Cambridge, 1994), pp 80-94; Edward Bever, 'Popular witch beliefs and magical practices' in, Levack (ed.), The Oxford handbook of witchcraft, pp 56-9; Walsham, Providence, pp 84-95, quote from p 95.

44 Oldridge, The devil, pp 134-160; Sharpe, Instruments of darkness, pp 70-5; Levack (ed.), 'Introduction' in, The Oxford handbook of witchcraft, pp 7-8.

45 On witchcraft and soteriology see, Stearne, pp 26-7, 30-2; Malcolm Gaskill, 'Witchcraft, emotion and imagination in the English civil war' in, John Newton (ed.), Witchcraft and the Act of 1604 (Leiden, 2006), pp 173-4; Laura Kounine "The devil used her sins": despair, confession and salvation in a seventeenth-century witch-trial', History of emotions: insights into research (Jan., 2014), pp 1-4 (doi: 10.14280/08241.20). Though some preachers tried to avoid the topic since it made the promotion of moral responsibility more complicated; on this see Susan Hardman Moore, 'Reformed theology and puritanism' in, Paul Nimmo and David Ferguson (eds), The Cambridge companion to reformed theology (Cambridge, 2016), pp 202-9.

46 Timbers, 'Witches sect', p 37; Stearne, pp 26-7, 30-2; Gaskill 'Witchcraft, emotion and imagination', pp 170-4.

47 Walsham, Providence, p 95.

48 BL, Add. MS, 27402, f. 108; Stearne, pp 26-32.

49 Stearne, p 60.

50 Judith Matlby, 'Suffering and surviving: the civil wars, the Commonwealth and the formation of "Anglicanism", 1642-60' in, Christopher Durston and Judith Maltby (eds), Religion in revolutionary England (Manchester, 2006), pp 170-1; Valletta, Witchcraft, magic and superstition in England, 1640-70, pp 6, 63-93.

51 Cited in Crawford Gribben, John Owen and English Puritanism: experiences of defeat (Oxford, 2016), p 57.

52 BL, Add. MS 4275, f. 173 (1647).

53 Stearne, p 60.

54 Gaskill, Witchfinders, pp 147-9; Diane Purkiss, 'Desire and its deformities: fantasies of witchcraft in the English civil war', The Journal of Medieval and Early Modern Studies, xxvii, no. 1 (1997), pp 103-32; Valletta, Witchcraft, magic and superstition, pp 54-7,147-8.

55 Ewen, Witch hunting and witch trials, pp 310-11; Mark Stoyle, The black legend of Prince Rupert's dog: witchcraft and propaganda during the English Civil War (Liverpool, 2011).

56 Gaskill, Witchfinders, pp 145-50; Peter Elmer, 'Towards a politics of witchcraft in early modern England' in, Stuart Clark (ed.), Languages of witchcraft: narrative, ideology and meaning in early modern culture (Basingstoke, 2001), pp 108-11; Peter Elmer, 'Saints or sorcerers: Quakerism, demonology and the decline of witchcraft in seventeenth-century England' in, Barry, Hester and Roberts (eds), Witchcraft in early modern Europe, pp 162-7.

57 For more on this with regards to providentialism and puritanism see, Walsham, Providence.

58 Clark, Thinking with demons, pp 49-53.

59 Glen Burgess, 'Was the English Civil War a war of religion? The evidence of political propaganda', Huntington Library Quarterly, lxi, no. 2 (1998), pp 173-201.

60 On this see, Walsham, Providence, pp 135-42.

61 Gribben, John Owen, pp 53-4, quote on p 53; in contrast to Burgess' argument, John Owen seems to have viewed the Civil War as a 'holy war' and urged fellow Puritans to crusade against the threat of Arminianism. Also see, Elmer, 'Saints or sorcerers', pp 162-6; Clark, Thinking with demons, pp 62-4. 
62 Oldridge, The devil, pp 84-9; C. Scott Dixon, The Reformation in Germany (Oxford, 2002), pp 178-80; Stuart Clark, 'Protestant demonology: sin, superstition, and society (c.1520-c.1630)' in, Bengt Ankarloo and Gustav Henningsen (eds), Early modern European witchcraft: centres and peripheries (Oxford, 1990), pp 45, 53-4.

63 Gribben, John Owen, pp 44-54; William Shiels, 'English Catholics at war and peace' in, Durston and Maltby (eds), Religion in revolutionary England, pp 137-8.

64 Gaskill, Witchfinders, pp 23, 104, 191, 242-3; Elmer, 'Towards a politics of witchcraft', p 109.

65 John Morrill (ed.), The impact of the English Civil War (London, 1991), pp 10-2; Shiels, 'English Catholics at war and peace', p 137.

66 Timothy Bridges, “Down with it, even to the ground": William Dowsing's reception of the iconoclastic rationale' ( $\mathrm{PhD}$ thesis, University of Edinburgh, 2009), pp 28-76, quote on p 125; Trevor Cooper (ed.), The journal of William Dowsing: iconoclasm in East Anglia during the English Civil War (Woodbridge, 2001); Elmer, 'Towards a politics of witchcraft', pp 109, 117; Sharpe, Instruments of darkness, p 142; Gaskill, Witchfinders, pp 24-5, 78, 82; Gaskill, 'The Matthew Hopkins trials', iii, p xxvi; Elmer, Witchcraft, witch-hunting and politics, p 126. Dowsing can be located in Laxfield, Suffolk, and in Lawford, Essex, through parish records, which note his wife's death and his child's baptism in May 1640: ERO, D/P 347/1/1. This is supported by annotations in his copy of, John Fit, A diamond most precious (London, 1577), sig. O2v, in which he wrote: 'I R[ead] this Booke June 6 [and] 71640 a month want 2 days after my wives death I have cause to eat my bread with ashes'; see Folger Shakespeare Library, STC 10929, item note: HH87/3.

67 Lowes had been in conflict with his parishioners since 1614, and had been suspected of witchcraft since then, too; see, R.H., A magazine of scandall (London, 1642); BL, Add. MS, 27402, f. 114; C. L'Estrange Ewen, The trials of John Lowes, clerk (London, 1937); Ewen, Witchcraft and demonianism, pp 291-2.

68 Elements of this can also be seen in, BL, Add. MS 4275, f. 173. Cooper (ed.), The journal of William Dowsing; Holmes (ed.), The Suffolk Committee for Scandalous Ministers (Ipswich, 1970); Elliot Vernon, 'A ministry of the gospel: the Presbyterians during the English Revolution' in, Durston and Maltby (eds), Religion in revolutionary England, pp 116-8; F. D. Dow, Radicalism in the English Revolution 1640-1660 (Oxford, 1985), p 35, and passim, for an overview of radical religious movements.

69 Elmer, Witchcraft, witch-bunting and politics, pp 131-8; Oldridge, The devil, pp 161-2; Peter Elmer, 'Towards a politics of witchcraft', pp 101-18. Oldridge and Davies argue that in the 1640s anti-Catholicism was a factor, not the sole cause. There is no concrete evidence to directly link witch-hunting with 'priest-hunting'; for this argument see Macfarlane, Witchcraft, pp 187-80.

70 J.C. Davis, 'Living with the living God: radical religion and the English Revolution' in, Durston and Maltby (eds), Religion in revolutionary England, pp 22-3.

71 Walsham, Providence, pp; 138-41; Bridges, 'William Dowsing', pp 28, 76, $122-9,159$.

72 ERO, T/A 418/127/10-1; ERO, T/A 418/127/60; ASS 35/83/1/10; ASS 35/86/1/11; ASS 35/86/1/60; Elmer, 'Towards a politics of witchcraft', pp 109-11; Ewen, Witch hunting and witch trials, pp 223-4, 227; Stearne, pp 14-6; Ewen, Witchcraft and demonianism, pp 266-7; Gaskill, Witchfinders, p 48.

73 Notestein, A history of witchcraft, pp 195-7. 
74 Sharpe, Instruments of darkness, pp 140-1; Gaskill, Witchfinders, p 41; ERO, T/P 51, Mistley and Manningtree records compiled by W.K.S. King.

75 Gaskill, 'Fear made flesh', p 83; Davies, Four centuries of witchcraft belief, pp 126-8; Stearne, pp 14-5.

76 ERO, T/A 418/116; ASS 35/80/3; ERO, T/A 418/120; ERO, ASS 35/84/2; ERO, T/A 418/127; ASS 35/86/1; Davies, Four centuries of witchcraft belief, pp 126-8; Gaskill, Witchfinders, pp 35, 127; Macfarlane, Witchcraft, p 175.

77 Gaskill, Witchfinders, pp 35-6; Notestein, A history of witchcraft, p 167; Christopher W. Brooks, 'Grimston, Sir Harbottle, second baronet (16031685)', ODNB (Oxford, 2004) (doi:10.1093/ref:odnb/11640) (Accessed: May, 2016); although this article is for Sir Grimston's son of the same name, biographical information on the first baronet is included. For Grimston's involvement in government during 1640 s see ESRO, D/Y 2/8, Morant manuscripts, Volume 8, 'C.XLVII', 1550-1688, pp 23, 27, 31-2, 37-8, 51, 62, 67, 73, 109, 232; for evidence of his financial clout his see, ESRO, D/DH VIA64; ESRO, D/ DH VIB20.

78 Gaskill, Witchfinders, p 36.

79 On failure to reintegrate into society due to witchcraft see, Mary Douglas, $P u$ rity and danger: an analysis of the concepts of pollution and taboo (London, 1966, reprint 2001), pp 99-100. For details on Bowes and West see, ERO, T/A 418/120; ASS 35/84/2; Gaskill, Witchfinders, p 37. The Hart family is an example of others who seized the opportunity to convict witches. They believed that the Wests had bewitched them in 1638 and made a formal accusation which failed. The Harts tried again in in 1645, providing testimony against the Wests; see, ERO, T/A 418/127/19 and 33; ASS 35/86/1/19 and 33; Macfarlane, Witchcraft, p 175.

80 ERO, T/A 418/127/97; ESRO, HD 36/A/163; Thomas, Religion and the decline, p 545; Durston, Witchcraft \& witch trials, p 200; Gaskill, Witchfinders, pp 120-1, 124; Notestein, A history of witchcraft, p 172; Stearne, p 25.

81 Davies, Four centuries of witchcraft belief, p 97.

82 Sharpe, Instruments of darkness, pp 82,100-2, 139; for references to earlier pamphlets see Stearne, p 11.

83 Davies, Four centuries of witchcraft belief, pp 126-8; Gaskill, 'The Matthew Hopkins trials', iii, pp 331, 489-94.

84 Notestein, A history of witchcraft, $\mathrm{p} 172$.

85 ESRO, D/DH VIA64; ESRO, D/DH VIB20; Macfarlane, Witchcraft, p 144; Gaskill, Witchfinders, pp 35-6.

86 Macfarlane, Witchcraft, p 143; Gaskill, 'The Matthew Hopkins trials', iii, pp xxvii-xxviii; Sharpe, Instruments of darkness, pp 142-3; ESRO, D/Y 2/8, Morant manuscripts, Volume 8, 'C.XLVII', 1550-1688. For Bowes and Grimston's relationship see for example, ESRO, Q/SR 335/81; ERO, T/A 418/127; ERO, T/A 418/120; ERO, T/A 418/116.

87 Gaskill, Witchfinders, p 152.

88 Ibid., pp 152-3; Sharpe, Instruments of darkness, p 141.

89 Stearne, pp 54-5.

90 Valletta, Witchcraft, magic and superstition, p 5; Gaskill, 'The Matthew Hopkins trials', iii, p xxviii. 
91 Davies, Four centuries of witchcraft belief, p 145; Notestein, A history of witchcraft, p 178; Davies does not provide a reference for this evidence. On Fairclough also see Deacon, Matthew Hopkins, pp 126-8; Deacon admits that the content of Fairclough's sermon is not extant, but suggests that it may have been moderate in tone. This is reiterated in Gaskill, 'The Matthew Hopkins trials', iii, p xxviii, where Fairclough and Calamy were said to hold moderate beliefs, with regards to witchcraft prosecution.

92 Notestein, A history of witchcraft, p 178; Gaskill, Witchfinders, pp 153-4; Andrew Hopper, Black Tom: Sir Thomas Fairfax and the English Revolution (Manchester, 2007), pp 101-2; John Coffey, 'The toleration controversy during the English Revolution' in, Durston and Maltby (eds), Religion in revolutionary England, p 46. For an example of Edmund Calamy's sermons, An indictment against England (London, 1645).

93 ERO, T/A 418/127; ASS 35/86/1; Macfarlane, Witchcraft, pp 137, 142-4.

94 Ibid., p 137; ERO, T/A 418/127/12-3, 33 and 82; Ewen, Witch hunting and witch trials, pp 224, 229-30.

95 ERO, T/A 418/127/10; Macfarlane, Witchcraft, p 143; Ewen, Witch hunting and witch trials, p 223; Gaskill, 'The Matthew Hopkins trials', iii, p xxviii.

96 Gaskill, Witchfinders, p 37; Frances Timbers, 'Witches sect', p 25; ERO, D/P 343/1/1-12.

97 Gaskill, Witchfinders, pp 37, 60; Timbers, 'Witches sect', pp 25-7; Deacon, Matthew Hopkins, $\mathrm{p} 73$, disagrees with Timbers, stating that it is unlikely that Hopkins was related to Thomas Witham, although he seems uncertain commenting, 'but nevertheless the dates fit in'.

1 Stearne, p 42.

2 Gaskill, Witchfinders, p 38.

3 Bunn and Geis, A trial of witches, $\mathrm{p} 142$.

4 Notestein, A history of witchcraft, $\mathrm{p} 166$.

5 Briggs, Witches \& neighbours, p 53; for Hopkins's religious belief, see Macfarlane, Witchcraft, pp 140, 144, 186.

6 Timbers, 'Witches sect', pp 27-8; Gaskill, Witchfinders, 41; Gaskill, 'The Matthew Hopkins trials', iii, p 331.

7 Coffey, 'The toleration controversy', p 47; Chad Van Dixhoorn (ed.), The minutes and papers of the Westminster Assembly, 1643-1652 (5 vols, Oxford, 2012), i, p xiv.

8 Crawford Gribben, Evangelical millennialism in the trans-Atlantic world, 1500-2000 (Basingstoke, 2011), pp 37-50.

9 The printed literature on demonology was authored by puritan clergymen well versed in English and European texts, including Richard Bernard, William Perkins, George Gifford and Richard Baxter. Stearne undoubtedly absorbed and engaged with their ideas prior to disseminating his own theories in print; see Thomas, Religion and the decline, pp 569-80; Sharpe, Instruments of darkness, pp 193-6, 239-41; Clark, Thinking with demons, pp 533-4.

10 Davies, Four centuries of witchcraft belief, attributes English witch-hunting to zealous puritanism. 
11 Dixhoorn, Westminster Assembly, i, pp x, xvi, 28-9; John Coffey and Paul Lim (eds), 'Introduction' in, The Cambridge companion to Puritanism (Cambridge, 2008), pp 1-11; Dewey Wallace, Puritans and predestination: grace in English Protestant theology (Chapel Hill, 1982), pp vii-viii.

12 Sharpe, 'The Devil in East Anglia', pp 237-8; ERO, T/A 418/127; ERO, ASS 35/86/1; ASS 35/83/1.

13 Stearne, pp 14-5.

14 Macfarlane, Witchcraft, pp 137, 140-4, 190; Gaskill, Witchfinders, pp 119-24.

15 William Hunt, The Puritan moment: the coming of revolution in an English county (Massachusetts, 1983), $\mathrm{p}$ x.

16 Malcolm Gaskill, 'Fear made flesh'; Morrill (ed.), The impact.

17 Andrew Bradstock, Radical religion in Cromwell's England: a concise history from the English Civil War to the end of the Commonwealth (London, 2011), pp 118-9; Fredric Baumgartner, Longing for the end: a history of millennialism in western civilisation (London, 1999), pp 103-8; Edwin Tay, 'Puritan demonology in the culture of "the Godly", Church \& Society in Asia Today, xv, no. 3 (Dec., 2012), pp 145-50. Glen Burgess, however, stresses that this has been exaggerated and that it was conceptualised as a just-war rather than a religious one; see, Burgess, 'Was the English Civil War a war of religion?', pp 173-201.

18 Coffey, 'The toleration controversy', pp 46-7; Christopher Hill, Antichrist in seventeenth century England (revised edn., London, 1990); Clark, Thinking with demons, pp 62-5.

19 ERO, T/A 418/127/97; ESRO, HD 36/A/163; Thomas, Religion and the decline, p 545; Durston, Witchcraft \& witch trials, p 200; Gaskill, Witchfinders, pp 120-4; Notestein, A history of witchcraft, p 172.

20 Sharpe, Instruments of darkness, pp 141-4.

21 Kenneth Shipps, 'The "Political Puritan", Church History, xlv, no. 2 (June, 1976), pp 196-205, quote on p 204.

22 Quaife, Godly zeal, p 182; Notestein, A history of witchcraft, pp 164, 201.

23 Hill, Antichrist, p 157.

24 Gaskill, Witchfinders, $\mathrm{p} 73$.

25 Sir Harbottle Grimston (junior), Mr. Grymstons speech in Parliament upon the accusation and impeachment of William Laud (London, 1641).

26 Elmer, Witchcraft, witch-hunting and politics, p 117; for Smith, see Hill, Antichrist, pp 87-8. For an interesting parallel, compare the backdrop to the East Anglian witch-hunt to a witchcraft case in seventeenth-century Rye, Sussex; see, Annabel Gregory, 'Witchcraft, politics and "good neighbourhood" in early seventeenth-century Rye', Past \& Present, cxxxiii, no. 1 (1991), pp 31-66.

27 See, Christopher Durston and Jacqueline Eales (eds), 'Introduction: the Puritan ethos, 1560-1700' in, The culture of English Puritanism, 1560-1700 (Basingstoke, 1996), pp 16-7.

28 Ibid.; see, Kai Erikson, Wayward Puritans: a study in the sociology of deviance (New York, 1966), p 49; Kevin Killeen, The political Bible in early modern England (Cambridge, 2017).

29 Notestein, A history of witchcraft, p 166. 
30 Dixhoorn, Westminster Assembly. The Assembly's members were far more interested in discussing Scripture and their Confession of Faith.

31 Stearne, sig. A2v; Gaskill, Witchfinders, pp 269-70.

32 Bernard, Guide to grand-jury men (London, 1627); for a brief description of Bernard see, Sharpe, Instruments of darkness, pp 82, 100-2. All of the verses Stearne quoted are analogous to those found in the AKJV rather than the Geneva Bible, which was popular in seventeenth-century England.

33 Stearne, sig. A2, pp 4, 9. For a list and brief contextualisation of stock-verses used by sixteenth-century theologians see, Stuart Clark and P.T.J. Morgan, 'Religion and magic in Elizabethan Wales: Robert Holland's Dialogue on Witchcraft', Journal of Ecclesiastical History, xxvii, no. 1 (Jan., 1976), pp 33-5.

34 Stearne, p 48.

35 John Bastwick, The utter routing of the whole army of all the Independents (London, 1646), pp 573-4; Immanuel Bourne, A light from Christ (London, 1646), p 513; John Downame, Annotations upon all the books of the Old and New Testaments (London, 1645), pp 75-6; Thomas Edwards, A treatise against toleration and pretend liberty of conscience (London, 1647), pp 44-5, 48-9.

36 Stearne, sig. A3. For alternative uses of these passages in the 1640 s see, Elmer, Witchcraft, witch-hunting and politics, pp 95,106.

37 Stearne, p 7; Thomas Edwards, The third part of Gangraena (London, 1646), p 260; quote from Richard Allen, An antidote against heresy (London, 1648), preface.

38 Thomas Cobbet, A just vindication of the covenant (London, 1648), pp 93, 227; John Eachard, The axe, against sin and error (London, 1646), p 35; Walter Bridges, A catechisme for communicants, (London, 1645), p 58; John Gaule, Select cases of conscience (London, 1646), pp 203-4; The humble advice of the Assembly of Divines now by authority of Parliament sitting at Westminster, concerning a confession of faith (London, 1647), chap. 28. Hereafter referenced as Confession of faith.

39 For a discussion on the translation of 'familiar spirits' from Hebrew to English in the context of witchcraft see, P. G. Maxwell-Stuart, 'Astrology, magic and witchcraft' in, Andrew Hatfield (ed.), The Oxford handbook of English prose, 1500-1640 (Oxford, 2013), pp 377-8.

40 Stearne, sig. A3, p 3.

41 Ibid., p 52.

42 Ibid., p 6.

43 Sir Thomas Browne, Pseudodoxia Epidemica (London, 1646), p 107; see also Thomas Browne, Religio medici (London, 1642), pp 56-7; Gaskill, Witchfinders, p 237; Elmer, Witchcraft, witch-hunting and politics, pp 227-8.

44 Gaule, Select cases, pp 10, 62-7, 106-8; HA, AH16:dated 1687/29; see Elmer, Witchcraft, witch-hunting and politics, pp 135, 158-9.

45 Richard Baxter, The saints everlasting rest (London, 1650), pp 237-8.

46 Maxwell-Stuart, 'Astrology, magic and witchcraft', pp 337-8; Stearne, sig. A3, pp 4, 40, 57.

47 Stearne, sig. A3.

48 Also see the 1599 Geneva Bible's annotations for Gen. 3, 1 Sam. 28, Mark 5; Ian Green, Print and Protestantism in early modern England (Oxford, 2000), pp 73-82; Arthur Jackson, Annotations upon the remaining historicall part of the Old Testament (London, 1646), pp 326-7; Joseph Caryl, An exposition with practical observations (London, 1648), p 243.

49 Johnstone, The devil and demonism, pp 5-6. Compare to, Hill, Antichrist, pp 78, 85-95, 131-8. 
50 Johnstone, The devil and demonism; Elmer, Witchcraft, witch-hunting and politics; Ian Bostridge, Witchcraft and its transformations, c.1650-c.1750 (Oxford, 1997).

51 Stearne, pp 58-9.

52 Arthur Wilson, 'Observations of God's providence in the tract of my life' in, Francis Peck (ed.), Desiderata curiosa (London, 1779), pp 475-7.

53 Stearne, p 3.

54 Edward Leigh, A treatise of divinity (London, 1646), pp 8-10; Gaule, Select cases, p 123; see Thomas, Religion and the decline, pp 90-134, for a list of more sixteenth- and seventeenth-century theologians with this outlook; for a general overview see, Walsham, Providence.

55 Michelle Brock, 'Internalizing the demonic: Satan and the self in early modern Scottish piety', Journal of British Studies, liv (Jan., 2015), pp 23-43.

56 Durston and Eales, 'Introduction', pp 8-13; Confession of faith, chap. 9.

57 Stearne, $\mathrm{p} 1$.

58 Confession of faith, chap. 6.

59 Stearne, pp 1-2. For contemporary references on demonic covenants see, Bourne, A light from Christ, p 513; Leigh, A treatise of divinity, pp 112-5; Edwards, A treatise against toleration, pp 48-9; Downame, Annotations, pp 75-6. Numerous trial pamphlets also provide examples: see, Anon., The examination, confession, triall, and execution, of Joane Williford (London, 1645); Anon., A true relation of the araignment of thirty witches at Chensford (London, 1645); H. F., A true and exact relation. On demonic pacts and covenanting theology see Elizabeth Reis, 'Witches, sinners and the underside of Covenant theology' in, Brian Levack (ed.), New perspectives on witchcraft, magic and demonology: demonology, religion, and witchcraft, $\mathrm{i}$, pp 271-86.

60 Stearne, p 2.

61 Johnstone, The devil and demonism, pp 142-74; Reis, 'Witches, sinners', pp 271-3, 273, 283-4.

62 Stearne, p 56; on parallels with crime narratives see, Johnstone, The devil and demonism, pp 142-74.

63 See, Confession of faith, chaps 5, 10-1, 15, 18; Vernon, 'A ministry of the gospel: the Presbyterians during the English Revolution', p 116.

64 Stearne, p 14.

65 Seventeenth-century murder and witchcraft pamphlets narrated moralistic tales of penitent sinners who were sermonised by ministers while in prison, resulting in conversion experiences. This ensured their salvation before execution; see Bernard Capp, England's culture wars: Puritan reformation and its enemies in the Interregnum, 1649-1660 (Oxford, 2013), pp 74-5.

66 Bernard, Guide, pp 237-41; National Trust, Tatton Park (Cheshire), Nehemiah Wallington, Great marcys continued (London, 1645-58), p 181, Tatton Park MS 68.20 (Available at: http://luna.manchester.ac.uk/luna/servlet/detail/ Manchester 91 1 241032 116993:Of-the-witches-in-Essex) (Accessed: June, 2018); Gaule, Select cases, pp 197-203; George Langford, Manassehs miraculous metamorphosis (London, 1621); also see, BL, Royal MS, 17 C.XXIII, 'Touchstone of witches'. Elmer, Witchcraft, witch-hunting and politics, pp 72, 105-6, notes that Langford's view was consonant with the Arminian doctrine of universal salvation.

67 Rita Voltmer, 'The witch in the courtroom: torture and the representation of emotion' in, Laura Kounine and Michael Ostling (eds), Emotions in history of witchcraft (London, 2016), pp 97-116.

68 Stearne, p 48.

69 Ibid., p 61. 
70 Ibid.

71 Wallace, Puritans and predestination, pp viii-ix; Confession of faith, chaps 7, 10.

72 Michael Allen, 'Confessions' in, Nimmo and Ferguson (eds), Reformed theology, p 42; Paul Nimmo, 'Sacraments' in, idem, pp 84-5; Confession of faith, chaps 27-8; Folger Shakespeare Library, 'Letters to and from the Lenthall and Warcupp families [manuscript]', X.d.375 (7).

73 Confession of faith, chaps 18, 28; Peter Optiz, 'Huldrych Zwingli' in, Nimmo and Ferguson (eds), Reformed theology, p 126.

74 Gaskill, Witchfinders, p 80; Gaskill, 'The Matthew Hopkins trials', iii, p 494.

75 Confession of faith, chap. 8.

76 Stearne, sig. A3v.

77 Stearne, p 34.

78 Hopkins, Discovery.

79 Stearne, pp 38-9; H .F., A true and exact relation, pp 9-12; ERO, T/A 418/127/9 and 19; ERO, ASS 35/86/1/9 and 19.

80 Gaskill, Witchfinders, pp 57-8.

81 Stearne accused a neighbour of working on the Sabbath in 1651, resulting in a counter-accusation against him which took three years to resolve; see, Elmer, Witchcraft, witch-hunting and politics, p 126; Gaskill, Witchfinders, pp 275-6. Consequently, Stearne attended the Suffolk Quarter Sessions numerous times, see; ESRO, B 105/2/3, ff. 30v, 38v, 39, 45v, 89; ESRO, B105/2/4, f. 29.

82 Capp, England's culture wars, pp 119-20; Judith Maltby, 'Suffering and surviving: the civil wars, the Commonwealth and the formation of "Anglicanism”, 1642-60' in, Christopher Durston and Judith Maltby (eds.), Religion in revolutionary England (Manchester, 2006), pp 162-5.

83 Hopkins, Discovery, p 2; Timbers, 'Witches sect', pp 29-32; Coffey, 'The toleration controversy', $\mathrm{p} 45$.

84 Stearne, p 39.

85 Timbers, 'Witches' sect', pp 31-2; Stearne, p 38; ERO, T/A 418/127; ERO, ASS 35/86/1.

86 Timbers, 'Witches' sect', pp 29, 32.

87 Capp, England's culture wars, pp 119-20; Maltby, 'Suffering and surviving', pp 162-5.

88 Dan Beaver, 'Parish communities, civil war, and religious conflict in England' in, R. Po-Chia Hsia (ed.), A companion to the reformation world (Oxford, 2004), pp 317-8; Maltby, 'The formation of "Anglicanism”, pp 160-74; Stearne, p 38.

89 Bradstock, Radical religion, pp xiv-xv.

90 Ibid., pp 118-9; Baumgartner, Longing for the end, pp 103-8; Tay, 'Puritan demonology', pp 145-50; Clark, Thinking with demons, pp 62-5.

91 Stearne, pp 4, 58, 60.

92 Ibid., pp 58, 60; see also, Gaskill, 'The Matthew Hopkins trials', p 494.

93 Bridges, 'William Dowsing', pp 125-59.

94 Gribben, John Owen, p 106; Howard Hotson, Paradise postponed: Johann Heinrich Alsted and the birth of Calvinist millenarianism (Dordrecht, 2000), p 14.

95 Stearne, p 60; Gribben, Evangelical millennialism, pp xiii-iv; Jeffrey K. Jue, 'Puritan millenarianism in Old and New England' in, Coffey and Lim (eds), The Cambridge companion to Puritanism, pp 259-63.

96 Stearne, p 60.

97 Confession of faith, chaps 32-3.

98 Robert Baillie, The letters and journals of Robert Baillie, 1637-1662, ed. David Laing (Edinburgh, 1841), p 313. 
99 Gribben, Evangelical millennialism, pp 20-2, 28.

100 Ibid., pp 28-35; Robert Clouse, 'Johann Heinrich Alsted and English millennialism', Harvard Theological Review, lxii (1969), pp 193-6.

101 Hotson, Paradise postponed, pp 18, 20; Baumgartner, Longing for the end, pp 103-4; Richard Bauckham, Tudor apocalypse: sixteenth century apocalypticism, millenarianism and the English Reformation (Appleford, 1978), pp 208-9; Hill, Antichrist, pp 25-30.

102 Samuel Hartlib, The Hartlib Papers, papers 64/20/5A-6B, ed. by Mark Greengrass, Michael Leslie, and Michael Hannon (Sheffield, HRI Online Publications, 2013) (Available at: www.hrionline.ac.uk/hartlib); [William Sedgwick] Doomes-day: or, the great day of the Lords judgement, proved by Scripture (London, 1647), p 6. On attribution of this text to Sedgwick see, Eugene Weber, Apocalypses: prophecies, cults \& millennial beliefs through the ages (Toronto, 1999), pp 42, 144.

103 Timothy Weber, 'Millennialism', in Jerry Walls (ed.), The Oxford handbook of eschatology (Oxford, 2008), p 375; also see, BL, Add. MS 4275, f. 173 (1647).

104 Hotson, Paradise postponed, pp 4, 9; Gribben, Evangelical millennialism, pp 42-4, 49-50; Bauckham, Tudor apocalypse, p 210.

105 Robert Clouse, 'Rebirth of millenarianism' in, Peter Toon (ed.) Puritans, the millennium and the future of Israel: Puritan eschatology (reprint, Cambridge, 2002), pp 48-53.

106 Stearne, p 60.

107 Stearne, p 3.

108 John Webster, The displaying of supposed witchcraft (London, 1677), preface.

109 George Kittredge, Witchcraft in Old and New England (Cambridge, 1929), p 273; Gaskill, 'The Matthew Hopkins trials', pp 488-95; also compare Bernard to William Perkins, A discourse of the damned art of witchcraft (Cambridge, 1608). 


\title{
Bibliography
}

\author{
Manuscripts \\ Bodleian Library (University of Oxford) \\ Bod. Rawl., B.393, f. 384v \\ British Library (London) \\ BL, Add. MS 27402, ff. 104-21 \\ BL, Add. MS 4275 \\ BL, Lansdowne MS 101/6 (22 Jan-12 Feb, 1568) \\ BL, Royal MS, 17 C.XXIII, 'Touchstone of witches' \\ Cambridgeshire Archives (Cambridge) \\ CA, P30/11/1 \\ Cambridge University Library (Cambridge) \\ VCCt.III 38.1, 1, Vice-Chancellor's Court, 9 April 1642 \\ East Suffolk Record Office (Ipswich) \\ ESRO, B105/2/3, ff. 30v, 38v, 39, 45v, 89 \\ ESRO, B105/2/4, f. 29 \\ ESRO, D/Y 2/8, Morant manuscripts, Volume 8, 'C.XLVII', 1550-1688 \\ ESRO, D/DH VIA64 \\ ESRO, D/DH VIB20 \\ ESRO, FC105/D1/1, Hutchinson's notes \\ ESRO, HD 36/A/163 \\ ESRO, Q/SR 335/81 \\ Ely Diocesan Records (Cambridge University Library) \\ EDR, E12 1647/21 \\ Essex Record Office (Chelmsford) \\ ERO, ASS 35/24/H \\ ERO, ASS 35/80/3 \\ ERO, ASS 35/83/1 \\ ERO, ASS 35/84/2 \\ ERO, ASS 35/86/1 \\ ERO, D/DBa/O19 \\ ERO, D/DMs O32 \\ ERO, D/P 343/1/1 \\ ERO, D/P 347/1/1 \\ ERO, Q/RT41/526 \\ ERO, Q/SBa 2/45-6
}


ERO, Q/SBc 2/25-6

ERO, Q/SR 320/59

ERO, Q/SR 326/1-10

ERO, Q/RTh1/526

ERO, T/A 282/2

ERO, T/A 391/8, pp 3-6

ERO, T/A 418/37

ERO, T/A 418/116

ERO, T/A 418/120

ERO, T/A 418/127

ERO, T/P 51, Mistley and Manningtree records compiled by W.K.S. King

ERO, T/Z 597/1

Folger Shakespeare Library (Washington, D.C.)

Fit, John, A diamond most precious (London, 1577), STC 10929, item note: HH87/3, Dowsing's annotations

'Legal notebook of Thomas Birch [manuscript]', V.a.395

'Letters to and from the Lenthall and Warcupp families [manuscript]', X.d.375

'Spell to bind the seven sister fairies [manuscript on vellum]', X.d.234

Harvard University, Houghton Library (Massachusetts)

'Depositions in a witchcraft case: manuscript, 1601', MS Eng 925

'Joseph Glanvill, letter to Henry More, 13 March [1666/7]', MS Eng 855

'William Drage, Daimonomageia: manuscript', STC 21075

Huntingdonshire Archives (Huntingdon)

HA, AH16:dated 1687/29

HA, CON 2/4/3/9 (20 June 1654)

HA, CON 2/4/3/10 (Michaelmas 1654)

HA, CON 3/9/10 (27 June 1648)

HA, TORK: 15/105 (10 Dec., 1651)

National Trust, Tatton Park (Cheshire)

Nehemiah Wallington, Great marcys continued (London, 1645-58), pp 177-84,

Tatton Park MS 68.20 (Available at: http://luna.manchester.ac.uk/luna/servlet)

Norfolk Record Office (Norfolk)

NRO, DN/SUB 1/1, p. 139.

$\mathrm{NRO}, \mathrm{DN} / \mathrm{SUB} / 2 / 1$

NRO, DN/INV 51A/52

NRO, NCC will register Stockdell 19; MF/RO 237/4

Public Record Office (English National Archives, Kew)

PRO, E/79/246/20

PRO, E/134/2/Chas2/Mich5

PRO, SP24/10, ff. 102v-3r, 159r

PRO, SP24/78

PRO, PROB 11/187/248

PRO, PROB11/307/45

University of Sheffield (Sheffield)

Samuel Hartlib, The Hartlib papers, papers 64/20/5A-6B, edited by Mark Greengrass, Michael Leslie, and Michael Hannon (HRI Online Publications, 2013) (Available at: www.hrionline.ac.uk/hartlib).

West Suffolk Record Office (Bury St Edmunds)

WSRO, IC500/1/122/13 
WSRO, IC 500/2/65/9

WSRO, FL 600/4/1-2

\section{Primary Sources}

Ady, Thomas, A candle in the dark (London, 1656).

Ainsworth, Henry, Annotations upon the five bookes of Moses, the booke of the Psalmes, and the Song of Songs (London, 1627).

Allen, Richard, An antidote against heresy (London, 1648).

Andrews, Lancelot, The pattern of catechistical doctrine at large (London, 1650).

Anon., The true reporte of the form of a monstrous childe borne at...Colchester (London, 1562).

Anon., The true description of two monstrous chyldren [sic]...in Kent (London, 1565).

Anon., Certaine secrete wonders of nature (London, 1569).

Anon., A rehearsall both straung and true (London, 1579).

Anon., The most strange and admirable disconerie of the three witches of Warboys (London, 1593).

Anon., The second report of Doctor John Faustus (London, 1594).

Anon., The judgment of God shew'd upon Dr. John Faustus (London, 1600s, Printed by C. Brown and T. Norris).

Anon., The life and death of Lewis Gaufredy a priest of the Church of the Accoules in Marceilles in France (London, 1612).

Anon., Damnable practises of three Lincolne-shire witches (London, 1619).

Anon., The wonderful discoverie of the witchcrafts of Margaret and Phillip Flower (London, 1619).

Anon., A briefe description of the notorious life of John Lambe (London, 1628).

Anon., The tragedy of Doctor Lambe...to the tune of Gallants come away (London, 1628).

Anon., Witchcrafts strange and wonderful (London, 1635).

Anon., The just judgment of God shew'd upon Dr. John Faustus. To the tune of, fortune my foe (London, 1640).

Anon., The clothiers petition... of Suffolke, and the townes of Dedham and Langham in Essex (London, 1642).

Anon., A declaration, of a strange and wonderfull monster...in Lancashire (London, 1642).

Anon., The new yeares wonder (London, 1642).

Anon., A signe from Heaven, or, a fearefull and terrible noise heard in the ayre at Alborow in the county of Suffolk (London, 1642).

Anon., An exact description of Prince Rupert's malignant She-Money (London, 1643).

Anon., A most certain strange and true discovery of a witch (London, 1643).

Anon., A parley between Prince Ruperts dogge (London, 1643).

Anon., A dog's elegy, or Rupert's teares for... his beloved dog named Boy (London, 1644).

Anon., The examination, confession, triall, and execution, of Joane Williford (London, 1645).

Anon., Lawes against witches (London, 1645).

Anon., Signes and wonders (London, 1645). 
Anon., A true relation of the araignment of eighteene vvitches... at St. Edmunds-bury (London, 1645).

Anon., A true relation of the araignment of thirty witches at Chensford (London, 1645).

Anon., Severall apparitions seene in the ayre...in the counties of Cambridge, Suffolke, and Norfolke (London, 1646).

Anon., The devill seen at St. Albons (London, 1648).

Anon., Look to it London, threatned to be fired by wilde-fire-zeal (London, 1648).

Anon., The witch of Wapping (London, 1652).

Anon., Doctor Lambs darling (London, 1653).

Bacon, Francis, Novum organum scientiarum (London, 1620), ed. and trans. Thomas Fowler (Oxford, 1878).

Baillie, Robert, The letters and journals of Robert Baillie, 1637-1662, ed. David Laing (3 vols, Edinburgh, 1841), ii.

Baker, Richard, Meditations and disquisitions (London, 1640).

Bastwick, John, The utter routing of the whole army of all the Independents (London, 1646).

Baxter, Richard, The saints everlasting rest (London, 1650).

Bernard, Richard, Contemplative pictures (London, 1610).

Bernard, Richard, A guide to grand-jury men (London, 1627).

Boulton, Richard, A compleat history of magick, sorcery and witchcraft (London, 1715).

Boulton, Richard, A vindication of a compleat history of magick, sorcery and witchcraft (London, 1722).

Bourne, Immanuel, A light from Christ (London, 1646).

Bragge, Francis, A full and impartial account of the discovery of sorcery and witchcraft (London, 1712).

Bridges, Walter, A catechisme for communicants (London, 1645).

British Museum's Department of Manuscripts, A catalogue of the Harleian Manuscripts in the British Museum: with indexes of persons, places, and matters (4 vols, London, 1808-12).

Browne, Thomas, Religio medici (London, 1642).

Browne, Thomas, Pseudodoxia epidemica (London, 1646).

Burton, Richard, The anatomy of melancholy (Oxford, 1621).

Butler, Samuel, Hudibras in three parts written in the time of the late wars, ed. Ludwig Gantter (Stuttgart, 1855), part II, canto III, pp 133-48.

Calamy, Edmund, England's looking-glass (London, 1641).

Calamy, Edmund, An indictment against England (London, 1645).

Capel, Richard, Tentations [sic] their nature, danger, cure (London, 1633).

Caryl, Joseph, An exposition with practical observations (London, 1648).

Cobbet, Thomas, A just vindication of the covenant (London, 1648).

Cooper, Thomas, The mystery of witchcraft (London, 1617).

Cotta, John A short discoverie of the... practisers of physicke in England (London, 1612).

Dalton, Michael, The countrey justice (London, 1618, 1635).

Darrell, John, A true narration of the strange and grevous vexation by the Devil (London, 1600).

The diary of Rev. Ralph Josselin, 1616-1683, ed. E. Hockliffe (London, 1908). A diary or an exact journal, July 24-31 (London, 1645). 
Dixhoorn, Chad Van (ed.), The minutes and papers of the Westminster Assembly, 1643-1652 (5 vols, Oxford, 2012).

Downame, John, Foure treatises tending to disswade all Christians from foure no lesse hainous then common sinnes (London, 1609).

Downame, John, Annotations upon all the books of the Old and New Testaments (London, 1645).

Drage, William, A physical nosonomy (London, 1664).

Drage, William, Daimonomageia (London, 1665).

E. G., A prodigious and tragic history... of six witches at Maidstone in Kent (London, 1652).

Eachard, John, The axe, against sin and error (London, 1646).

Edwards, Thomas, The third part of Gangraena (London, 1646).

Edwards, Thomas, A treatise against toleration and pretend liberty of conscience (London, 1647).

Fairclough, Samuel, The troublers troubled (London, 1641).

Fairfax, Edward, Daemonologia: a discourse on witchcraft, 1621, ed. William Grainge (Harrogate, 1882).

Filmer, Sir Robert, An advertisement to the jury-men of England (London, 1653).

Gaule, John, Select cases of conscience (London, 1646).

Gifford, George, A discourse of the subtill practises of devilles by witches (London, 1587).

Gifford, George, A dialogue concerning witches and witchcrafts (London, 1593).

Glanvill, Joseph, A blow at modern sadducism (London, 1668).

Glanvill, Joseph, Saducismus triumphatus (London, 1681).

Goodcole, Henry, The wonderfull discoverie of Elizabeth Sawyer (London, 1621).

Gouge, William, Of domesticall duties eight treatises...III particular duties of wives (London, 1622).

Grimston (junior), Sir Harbottle, Mr. Grymstons speech in Parliament upon the accusation and impeachment of William Laud (London, 1641).

H. F., A true and exact relation (London, 1645).

Harvey, William, On the motion of the heart and blood in animals (Frankfurt, 1628), trans. Robert Willis, in Charles Eliot (ed.), Scientific papers; physiology, medicine, surgery, geology, with introductions, notes and illustrations (New York, 1910), xxxviii, pp 63-147.

Hobbes, Thomas, Leviathan (London, 1651).

Hooke, Robert, Micrographia: or some physiological descriptions of minute bodies made by magnifying glasses (London, 1665).

Hopkins, Matthew, The discovery of witches (London, 1647).

Hutchinson, Francis, An historical essay concerning witchcraft (London, 1718).

Jackson, Arthur, Annotations upon the remaining historicall part of the Old Testament (London, 1646).

James VI and I, Daemonologie (Edinburgh, 1597).

Jonson, Ben, The alchemist (London, 1612).

Jorden, Edward, A discourse of natural bathes, and mineral waters (London, 1669).

L. P., Strange and wonderfull news of a woman which lived neer unto the famous city of London who had her head torn off from her body by the Divell (London, 1630).

Langford, George, Manassehs miraculous metamorphosis (London, 1621).

Langley, John, Gemitus columbae: the mournfull note of the dove (London, 1644). 
Leavitt, George A., \& Co., auctioneers, Catalogue of the library, manuscripts and prints of Rushton M. Dorman, esq., of Chicago, Illinois: the whole to be sold by auction... April 5th, 6th, 7th and 8th, 1886 (New York, 1886).

Leigh, Edward, A treatise of divinity (London, 1646).

Leigh, Sotheby and Son, auctioneers, A catalogue of the entire and curious library and manuscripts of the late Joseph Ritson, Esq. of Gray's Inn (London, Monday 5 Dec., 1803).

Marlowe, Christopher, The tragicall history of D. Faustus, as it hath bene acted by the right honorable the Earle of Nottingham his servants (London, 1604).

Marlowe, Christopher, The tragicall history of the life and death of Doctor Faustus (London, 1620, 1624, 1631).

Marshall, Stephen, A sermon preached before the House of Commons (London, 1640).

Michaelis, Sébastien, The admirable history of the possession and conversion of a penitent woman (London, 1613).

Middle Temple, Catalogus librorum bibliothece Honorabilis Societatis Medii Templi Londini. Ordine dictionarii dispositus (London, 1734).

More, Henry, An antidote against atheisme (London, 1653).

Osborne, Thomas, Catalogus bibliotheca Harleiance, in locos communes distributus cum indice auctorum (4 vols, London, 1744), iv.

P.F. [alternatively P.P. or R.P.], Gent., The historie of the damnable life and deserved death of Doctor John Faustus (London, 1592, 1608, 1610, 1622 1636, 1648).

Parliaments Post, 23 July-5 August (London, 1645).

A perfect diurnall of some passages in Parliament, 21-8 July (London, 1645).

Perkins, William, A discourse of the damned art of witchcraft (Cambridge, 1608, 1610).

Philips, John, The examination and confession of certaine wytches at Chensforde in the countie of Essex (London, 1566).

Potts, Thomas, The wonderfull disconerie of witches (London, 1613).

Puttick, [Thomas] and [William] Simpson, Catalogue of a very extensive, curious and valuable library comprising a larger collection than has hitherto ever been offered in one sale of rare, curious, and important works in Anglo-American literature (London, 1859).

R. H., A magazine of scandall (London, 1642).

Roberts, Alexander, A treatise of witchcraft (London, 1616).

[Sedgwick, William], Doomes-day: or, the great day of the Lords judgement, proved by Scripture (London, 1647).

Shower, Sir Bartholomew, Bibliotheca illustris Medii Templi Societatis (London, 1700).

Sion College Library, Catalogus universalis librorum omnium in bibliotheca Collegii Sionii apud Londinenses (London, 1650).

Slayter, William, The compleat Christian (London, 1643).

Sotheby, Wilkinson \& Hodge, Catalogue of the second portion of the library of rare books and important manuscripts, of the late James Crossley (1885).

The Spectator, 14 July 1711 in, Henry Morley (ed.), The Spectator: a new edition reproducing the original text (3 vols, London, 1891), i.

The Stationers' Company, A transcript of the registers of the worshipful Company of Stationers, from 1640-1708, A.D. (3 vols, 1913), i. 
'Statute of Artificers, 5 Eliz. 1 c. 4 (1563)' in, Alexander Luders (ed.), The statutes of the realm: printed by command of his majesty King George the third (11 vols, London, reprinted 1965), iv, part 1, pp 418-9.

Stearne, John, A confirmation and discovery of witchcraft (London, 1648).

Taylor John, A brief director for those that would send their letters to any parts of England, Scotland, or Ireland (London, 1642).

Tilney, Edmund, A briefe and pleasant discourse of duties in marriage (London, 1571).

Topsell, Edward, The history of four-footed beasts and serpents (London, 1658).

W. W., A true and just recorde ...of the witches, taken at S. Oses [sic] (London, 1582).

Webster, John, The displaying of supposed witchcraft (London, 1677).

The Weekly Account, 23-29 July (London, 1645).

Westminster Assembly, The humble advice of the Assembly of Divines now by authority of Parliament sitting at Westminster, concerning a confession of faith (London, 1647).

Whichcot, Benjamin, Select sermons of Dr. Whichcot (London, 1698).

Willis, Thomas, An essay of the pathology of the brain and nervous stock, trans. Samuel Pordage (London, 1681).

Wilson, Arthur, 'Observations of God's providence in the tract of my life' in, Francis Peck (ed.), Desiderata curiosa: or A collection of divers scarce and curious pieces relating chiefly to matters of English history (London, 1779), pp 460-83.

\section{Secondary Sources}

Anderson, Nancy, 'Linton, Elizabeth [Eliza] Lynn (1822-1898)', ODNB (Oxford, 2004) (Available at doi:10.1093/ref:odnb/16742) (Accessed: Dec., 2019).

Andrews, William (ed.), Bygone Leicestershire (London, 1892).

The Angus Library and Archive: Baptist History Project (Oxford) (Available at: http://theangus.rpc.ox.ac.uk/?candidate=john-charles-foster) (Accessed: Dec., 2019).

Apps, Lara, and Andrew Gow, Male witches in early modern Europe (New York, 2003).

Ashdown-Hill, John, 'The Bosworth Crucifix,' Transactions of the Leicestershire Archaeological and Historical Society, lxxviii (2004), pp 83-96.

Attfield, Robin, 'Balthasar Bekker and the decline of the witch-craze: the old demonology and the new philosophy', Annals of Science, xlii, no. 4 (1985), pp 383-95.

Baker, Philip, 'The regicide' in, Michael Bradick (ed.), The Oxford handbook of the English Revolution (Oxford, 2015), pp 154-69.

Baptist Union of Great Britain and Ireland, The Baptist handbook for 1896 (London, 1896).

Barry, Jonathan, Marianne Hester and Gareth Roberts (eds), Witchcraft in early modern Europe: studies in culture and belief (Cambridge, 1996).

Barry, Johnathan, and Owen Davies (eds), Palgrave advances in witchcraft historiography (Basingstoke, 2007).

Barry, Johnathan, Witchcraft and demonology in south-west England, 1640-1789 (Basingstoke, 2012). 
Bauckham, Richard, Tudor apocalypse: sixteenth-century apocalypticism, millenarianism and the English Reformation (Appleford, 1978).

Baumgartner, Fredric, Longing for the end: a history of millennialism in western civilisation (London, 1999).

Beaver, Dan, 'Parish communities, civil war, and religious conflict in England' in, Richard Po-Chia Hsia (ed.), A companion to the reformation world (Oxford, 2004), pp 311-34.

Bedwell, C. E. A., A brief history of the Middle Temple (London, 1909) (Available at: www.middletemple.org.uk/library-and-archive/library/history-of-the-library).

Begley, Walter (ed.), Nova Solyma, the ideal city; or, Jerusalem regained (2 vols, New York, 1902).

Berry, Hellen, and Elizabeth Foyster (eds), 'Childless men in early modern England' in, The family in early modern England (Cambridge, 2007), pp 158-83.

Bettley, James, 'Clark, Charles (1806-1880)', ODNB (Oxford, 2004) (Available at doi:10.1093/ref:odnb/5457) (Accessed: Dec., 2019).

Bostridge, Ian, Witchcraft and its transformations, c.1650-c.1750 (Oxford, 1997).

Braddick, Michael, God's fury, England's fire: a new history of the English civil wars (London, 2009).

Bradstock, Andrew, Radical religion in Cromwell's England: a concise history from the English Civil War to the end of the Commonwealth (London, 2010).

Brauner, Sigrid, Fearless wives and frightened shrews: the construction of the witch in early modern Germany (Amherst, 1996).

Breuer, Heidi, Crafting the witch: gendering magic in medieval and early modern England (London, 2009).

Bridges, Timothy, "Down with it, even to the ground": William Dowsing's reception of the iconoclastic rationale' (PhD thesis, University of Edinburgh, 2009).

Briggs, Robin, Witches \& neighbours: the social and cultural context of European witchcraft (London, 1996, reprinted 2002).

Briggs, Robin, "'By the strength of fancie": witchcraft and the early modern imagination', Folklore, cxv, no. 3 (2004), pp 259-72.

Brock, Michelle, 'Internalizing the demonic: Satan and the self in early modern Scottish piety', Journal of British Studies, liv (Jan., 2015), pp 23-43.

Brooks, Christopher W., 'Grimston, Sir Harbottle, second baronet (1603-1685)', ODNB (Oxford, 2004) (Available at doi:10.1093/ref:odnb/11640) (Accessed: May, 2016).

Brownlow, Frank Walsh, Shakespeare, Harsnett, and the Devils of Denham (London, 1993).

Bulwer, Brig-General (ed.), The visitation of Norfolk in the year 1563 (Norwich, 1895), ii.

Bunn, Ivan, and Gilbert Geis, A trial of witches: a seventeenth century witchcraft prosecution (London, 1997).

Burd, Henry Alfred, Joseph Ritson: a critical biography (Illinois, 1916).

Burgess, Glen, 'Was the English Civil War a war of religion? The evidence of political propaganda', Huntington Library Quarterly, lxi, no. 2 (1998), pp 173-201.

Burr, George Lincoln, 'Review of The history of witchcraft and demonology; Geography of witchcraft; Malleus Maleficarum; Demoniality', The American Historical Review, xxxiv, no. 2 (Jan., 1929), pp 321-5.

Calder, Angus, 'Mackay, Charles (1812-1889)', ODNB (Oxford, 2004) (Available at doi:10.1093/ref:odnb/17555) (Accessed: Dec., 2019). 
Callow, John, Embracing the darkness: a cultural history of witchcraft (London, 2018). Cambers, Andrew, Godly reading: print, manuscript and Puritanism in England, 1580-1720 (Cambridge, 2011).

Cambridge University, A Cambridge Alumni Database: all alumni of the University of Cambridge, 1200-1900 (Available at: http://venn.lib.cam.ac.uk/Documents/ acad/enter.html) (Accessed: Dec., 2019).

Capp, Bernard, When gossips meet: women, family and neighbourhood in early modern England (Oxford, 2003).

Capp, Bernard, England's culture wars: Puritan reformation and its enemies in the Interregnum, 1649-1660 (Oxford, 2013).

Carr, Victoria, 'The witch's animal familiars in early modern southern England' (PhD thesis, University of Bristol, 2017).

Chisholm, Michael, 'Navigation and the seventeenth-century draining of the Fens', Journal of Historical Geography (Oct., 2006), xxxii, no. 4, pp 733-40.

Clark, Charles (ed.), A true and exact relation...reprinted verbatim from the original edition (London, 1837).

Clark, Charles (ed.), A collection of rare and curious tracts, relating to witchcraft... between the years 1618 and 1664. Reprinted verbatim from the original editions (London, 1838).

Clark, Charles, 'Hearne’s Confirmation', Notes and Queries, v, series 1, no. 131 (1 May 1862), p. 416.

Clark, Sandra, The Elizabethan pamphleteers: popular moralistic pamphlets, 1580-1640 (London 1983).

Clark, Stuart, and P. T. J. Morgan, 'Religion and magic in Elizabethan Wales: Robert Holland's Dialogue on Witchcraft', Journal of Ecclesiastical History, xxvii, no. 1 (1976), pp 31-46.

Clark, Stuart, 'Inversion, misrule and the meaning of witchcraft', Past \& Present, lxxxvii (May, 1980), pp 98-127.

Clark, Stuart, 'Protestant demonology: sin, superstition, and society (c.1520-c.1630)' in, Bengt Ankarloo and Gustav Henningsen (eds), Early modern European witchcraft: centres and peripheries (Oxford, 1990), pp 45-54.

Clark, Stuart, Thinking with demons: the idea of witchcraft in early modern Europe (Oxford, 1999).

Clericuzio, Antonio, 'Webster, John (1611-1682), schoolmaster and polemicist', ODNB (Oxford, 2004) (Available at doi:10.1093/ref:odnb/28944) (Accessed: May, 2018).

Clouse, Robert, 'Johann Heinrich Alsted and English millennialism', Harvard Theological Review, lxii, no. 2 (1969), pp 189-207.

Clouse, Robert, 'The rebirth of millenarianism' in, Peter Toon (ed.), Puritans, the millennium and the future of Israel: Puritan eschatology (Reprinted, Cambridge, 2002), pp 42-65.

Clowes, H.A., 'Harvey and the Lancashire witches', British Medical Journal, ii, no. 3428 (Sept., 1926), pp 543-4.

Coffey, John, and Paul Lim (eds), 'Introduction' in, The Cambridge companion to Puritanism (Cambridge, 2008), pp 1-16.

Cohen, Esther, 'Law, folklore and animal lore', Past \& Present, cx (Feb., 1986), pp 6-37.

Cohn, Norman, Europe's inner demons: the demonization of Christians in medieval Christendom (2nd edition, London, 1993). 
The College of Wooster, 'English historical library of Wallace Notestein' (Available at: www.wooster.edu/academics/libraries/collections/collections/notestein/ english/) (Accessed: Dec., 2019).

Collier, Judith, Murray Longmore, and Keith Amarakone, Oxford handbook of clinical specialities (9th edition, Oxford, 2013).

Collins, Stephen, 'Crossley, James (1800-1883)', ODNB (Oxford, 2004) (Available at doi:10.1093/ref:odnb/6808) (Accessed: Dec., 2019).

Collinson, Patrick, 'England' in, Bob Scribner, Roy Porter and Mikulas Teich (eds), The Reformation in a national context (Cambridge, 1994), pp 80-94.

Cooper, Trevor (ed.), The journal of William Dowsing: iconoclasm in East Anglia during the English Civil War (Woodbridge, 2001).

Cottingham, John, Robert Stoothoff, and Dugald Murdoch (eds.), The philosophical writings of Descartes (3 vols, Cambridge, 1984).

Crabb, John, Graven images: the art of the woodcut (London, 2017).

Crawford, Patricia, 'Attitudes towards menstruation', Past and Present, xci, no. 1 (1981), pp 47-73.

Crossley, James, Potts's Discovery of witches in the county of Lancaster...with an introduction and notes by James Crossley, Esq (Manchester, 1845).

Crossley, James, 'Stearne's (not Hearne's) confirmation and discovery of witchcraft', Notes and Queries, v, series 1, no. 139 (June, 1852), p. 621.

Curtis, Rev. John, A topographical history of the county of Leicester (London, 1831).

Cuttica, Cesare, Sir Robert Filmer (1588-1653) and the patriotic monarch: patriarchalism in seventeenth-century political thought (Manchester, 2012).

Daly, Mary, Gyn/ecology: the metaethics of radical feminism (Boston, 1978).

Dalyell, John, The darker superstitions of Scotland (Edinburgh, 1834).

Darnton, Robert, 'What is the history of books?', Daedalus, cxi, no. 3, (Summer, 1982), pp 65-83.

Darr, Orna, 'The devil's mark: a sociocultural analysis of physical evidence', Continuity and Change, xxiv, no. 2 (Aug., 2009), pp 361-87.

Darr, Orna, Marks of an absolute witch: evidentiary dilemmas in early modern England (Farnham, 2011).

Dashwood, Rev. G. H. (ed.), The visitation of Norfolk in the year 1563 (Norwich, 1878), i.

Davidson, L. S., and J. O. Ward (eds), The sorcery trial of Alice Kyteler: a contemporary account (1324) together with related documents in English translation, with introduction and notes (Asheville, 2004).

Davies, Owen, Witchcraft, magic and culture 1736-1951 (Manchester, 1999).

Davies, Owen, Popular magic: cunning-folk in English history (London, 2003).

Davies, Owen, Grimoires: a history of magic books (Oxford, 2009).

Davies, R. Trevor, Four centuries of witch-beliefs: with special reference to the Great Rebellion (London, 1947).

Davies, S. F., The discovery of witches and witchcraft: the writings of the witchfinders (Brighton, 2007).

Davis, Natalie Zemon, Society and culture in early modern France (Stanford, 1975).

Deacon, John, Matthew Hopkins: Witch Finder General (London, 1976).

Demos, John, Entertaining Satan: witchcraft and the culture of early New England (updated edition, Oxford, 2004), 
Dickinson, Donald, 'Mr. Huntington and Mr. Brigham', The Book Collector, xlii, no. 4 (Winter, 1993), pp 509-13.

Dixon, C. Scott, The Reformation in Germany (Oxford, 2002).

Dolan, Frances, Dangerous familiars: representations of domestic crime in England, 1500-1700 (London, 1994).

Douglas, Mary, Purity and danger: an analysis of the concepts of pollution and taboo (London, 1966, reprinted 2001).

Dow, F. D., Radicalism in the English Revolution 1640-1660 (Oxford, 1985).

Dowd, Michelle, Women's work in early modern English literature and culture (New York, 2009).

Duckenfield, Bridget, College cloisters - married bachelors (Newcastle upon Tyne, 2013).

Durrant, Johnathan, Witchcraft, gender and society in early modern Germany (Leiden, 2009).

Durston, Christopher, and Jacqueline Eales (eds), 'Introduction: the Puritan ethos, 1560-1700' in, The culture of English Puritanism, 1560-1700 (Basingstoke, 1996), pp 1-17.

Durston, Christopher, and Judith Maltby (eds), Religion in revolutionary England (Manchester, 2006).

Durston, Gregory, Witchcraft \& witch trials: a history of English witchcraft and its legal perspectives, 1542 to 1736 (Chichester, 2000).

Eales, Jacqueline, Women in early modern England, 1500-1700 (London, 1998).

Easlea, Brian, Witch-hunting, magic and the new philosophy: an introduction to the debates of the scientific revolution, 1450-1750 (Sussex, 1980).

Eaton, Scott, 'Witch-finding: from 17th century science to 21st century superstition', QJM: An International Journal of Medicine, cxii, no. 5 (May 2019), pp 385-6 (Available at doi:10.1093/qjmed/hcz047).

Ehrenreich, Barbara, and Deirdre English, Witches, midwives and healers: a history of women healers (New York, 1973, reprinted 2010).

Elmer, Peter, The library of Dr John Webster: the making of a seventeenth-century radical (Medical History Supplement, no. 6, London, 1986).

Elmer, Peter, 'Towards a politics of witchcraft in early modern England' in, Stuart Clark (ed.), Languages of witchcraft: narrative, ideology and meaning in early modern culture (Basingstoke, 2001), pp 101-18.

Elmer, Peter, 'Cotta, John (1575?-1627/8), physician', ODNB (Oxford, 2004) (Available at doi:10.1093/ref:odnb/6393) (Accessed: May, 2018).

Elmer, Peter, 'East Anglia and the Hopkins trials, 1645-1647: a county guide' (Available at: http://practitioners.exeter.ac.uk/wp-content/uploads/2014/11/ Eastanglianwitchtrialappendix2.pdf) (Accessed: Mar., 2018).

Elmer, Peter, Witchcraft, witch-hunting and politics in early modern England (Oxford, 2016).

Erikson, Kai, Wayward Puritans: a study in the sociology of deviance (New York, 1966).

Evans, E. P., The criminal prosecution and capital punishment of animals (London, 1906).

Evans-Pritchard, E. E., Witchcraft, oracles and magic among the Azande (London, 1937).

Ewen, C. L' Estrange, Witch hunting and witch trials (London, 1929).

Ewen, C. L' Estrange, Witchcraft and demonianism (London, 1933). 
Ewen, C. L' Estrange, The trials of John Lowes, clerk (London, 1937).

Fincham, Kenneth, 'Abbot, George (1562-1633)', ODNB (Oxford, 2004) (Available at doi:10.1093/ref:odnb/4) (Accessed: Dec., 2019).

Foster, John Charles, 'An unrecorded first edition of Bunyan', Transactions of the Baptist Historical Society, i, no. 2 (Apr., 1909), pp 92-9.

Foster, John Charles, 'Early Baptist writers of verse', Transactions of the Baptist Historical Society, iii, no. 2 (Oct., 1912), pp 96-107.

Fox, Adam, Oral and literate culture in England 1500-1700 (Oxford, reprinted 2003).

Fraser, Antonia, The weaker vessel: women's lot in seventeenth-century England (London, 1985).

Frazer, Sir James, The golden bough: a study in magic and religion (abridged edition, London, 1950).

Fudge, Erica, 'The animal face of early modern England', Theory, culture \& society, $\mathrm{xxx}$, no. 7 (2013), pp 177-98.

Garrett, Christina, Marian exiles: a study in the origins of Elizabethan Puritanism (Cambridge, 1938).

Garrett, Julia, 'Witchcraft and sexual knowledge in early modern England', Journal for Early Modern Cultural Studies, xiii, no. 1 (Winter, 2013), pp 32-72.

Gaskill, Malcolm, 'Witchcraft and power in early modern England: the case of Margaret Moore' in, Jenny Kermode and Garthine Walker (eds), Women, crime and the courts in early modern England (London, 1994), pp 125-45.

Gaskill, Malcolm, 'The devil in the shape of a man: witchcraft, conflict and belief in Jacobean England', Historical Research, lxxi, no. 175 (June, 1998), pp 142-71.

Gaskill, Malcolm, Crime and mentalities in early modern England (Cambridge, 2003).

Gaskill, Malcolm, Witchfinders: a seventeenth-century English tragedy (London, 2005).

Gaskill, Malcolm, 'Witchcraft and evidence in early modern England', Past \& Present, cxcviii (Feb., 2008), pp 59-70.

Gaskill, Malcolm, 'Witchcraft, emotion and imagination in the English civil war' in, John Newton and Jo Bath (eds), Witchcraft and the Act of 1604 (Leiden, 2008), pp 16-78.

Gaskill, Malcolm, 'Fear made flesh: the English witch-panic of 1645-7' in, David Lemmings and Claire Walker (eds), Moral panics, the media and the law in early modern England (Basingstoke, 2009), pp 78-96.

Gaspey, Thomas, The witch-finder, or the wisdom of our ancestors: a romance (3 vols, London, 1824).

Geertz, Hildred, 'An anthropology of religion and magic, I', Journal of Interdisciplinary History, vi, no. 1 (Summer, 1975), pp 71-89.

Gevitz, Norman, "'The Devil hath laughed at the physicians": witchcraft and medical practice in seventeenth-century New England', Journal of the History of Medicine and Allied Sciences, lv, no. 1 (2000), pp 5-36.

Gibson, Marion, Reading witchcraft: stories of early English witches (London, 1999).

Gibson, Marion and Jo Ann Esra (eds), Shakespeare's demonology: a dictionary (London, 2014).

Gibson, Marion, Rediscovering renaissance witchcraft (New York, 2018). 
Gillis, John, 'Conjugal settlements: resort to clandestine and common law marriage in England and Wales, 1650-1850' in, John Bossy (ed.), Disputes and settlements: law and human relations in the West (Cambridge, 1983), pp 261-86.

Ginzburg, Carlo, The night battles: witchcraft and agrarian cults in the sixteenth and seventeenth centuries (Baltimore, 1983).

Golden (ed.), Richard, Encyclopaedia of witchcraft: the western tradition (4 vols, Santa Barbara, 2006).

Goldstone, J. A., 'The demographic revolution in England: a re-examination', Population Studies, xl, no. 1 (Mar., 1986), pp 5-33.

Goodare, Julian, Lauren Martin and Joyce Miller (eds), Witchcraft and belief in early modern Scotland (Basingstoke, 2008).

Gordon, Alex, 'Hopkins, Matthew' in, Sidney Lee (ed.), Dictionary of national biography (63 vols, London, 1891), xxvii.

Gorham, Geoffrey, 'Cartesian causation: continuous, instantaneous, overdetermined', Journal of the History of Philosophy, xlii, no. 4 (Oct., 2004), pp 389-423.

Gray, Joseph, The Queen's college of St. Margaret and St. Bernard in the University of Cambridge (London, 1899).

Green, Ian, Print and Protestantism in early modern England (Oxford, 2000).

Gregory, Annabel, "Witchcraft, politics and "good neighbourhood" in early seventeenth-century Rye’, Past \& Present, cxxxiii, no. 1 (1991), pp 31-66.

Gribben, Crawford, Evangelical millennialism in the trans-Atlantic world, 15002000 (Basingstoke, 2011).

Gribben, Crawford, 'Scottish Romanticism, evangelicalism and Robert Pollok's The course of time (1827)', Romanticism, xxi, no. 1 (2015), pp 25-36.

Gribben, Crawford, John Owen and English Puritanism: experiences of defeat (Oxford, 2016).

Guiley, Rosemary, The encyclopaedia of witches, witchcraft and wicca (3rd edition, New York, 2008).

Hadass, Ofer, Medicine, religion, and magic in early Stuart England: Richard Napier's medical practice (Pennsylvania, 2018).

Hall, David, Worlds of wonder, days of judgement: popular religious belief in early New England (Massachusetts, 1990).

Harley, David, 'Historians as demonologists: the myth of the midwife-witch', The Society for the Social History of Medicine, iii, no. 1 (1990), pp 1-26.

Harris, Anthony, Night's black agents: witchcraft and magic in seventeenthcentury English drama (Manchester, 1980).

Harrison, Peter, 'Descartes on animals', The Philosophical Quarterly, xlii, no. 167 (Apr., 1992), pp 219-27.

Hartnell, Jack, Medieval bodies: life, death and art in the Middle Ages (London, 2019).

Harvard Graduates' Magazine Association, The Harvard Graduates Magazine, xiv (Boston, 1905-6).

Harvard University, Quinquennial catalogue of the officers and graduates of Harvard University, 1636-1895 (Massachusetts, 1895).

Harvard University, Annual reports of the president and the treasurer of Harvard College, 1903-1904 (Cambridge, 1905).

Hattab, Helen, 'Concurrence or divergence? Reconciling Descartes's physics with his metaphysics', Journal of the History of Philosophy, xlv, no. 1 (Jan., 2007), pp 49-78. 
Havery, Richard (ed.), The history of the Middle Temple (Oxford, 2011).

Helms, M. W., and J. S. Crossette, 'Rossiter, Edward (1618-69), of Somerby, Lincs', The history of Parliament: British political, social and local history (The History of Parliament Trust, 1964-2018) (Available at: www.historyofparliamentonline. org/volume/1660-1690/member/rossiter-edward-1618-69) (Accessed: July, 2018).

Hennepe, Meineke te, 'Of the fisherman's net and skin pores. Reframing conceptions of the skin in medicine, 1572-1714' in, H.F.J. Horstmanshoff, Helen King and Claus Zittel (eds), Blood, sweat, and tears: the changing concepts of physiology from antiquity into early modern Europe (Leiden, 2012), pp 523-50.

Hill, Christopher, Antichrist in seventeenth-century England (Revised edition, Oxford, 1990).

Hill, Christopher, The world turned upside down: radical ideas during the English Revolution (London, 1991).

Hole, Robert, 'Incest, consanguinity and a monstrous birth in rural England, January 1600', Social History, xxv, no. 2 (May, 2000), pp 183-99.

Holmes, Clive (ed.), The Suffolk committee for Scandalous Ministers (Ipswich, 1970).

Holmes, Clive, The Eastern Association in the English Civil War (New York, 1974).

Holmes, Clive, 'Popular culture? Witches, magistrates and divines in early modern England' in, Steven Kaplan (ed.), Understanding popular culture: Europe from the middle ages to the nineteenth century (Berlin, 1984), pp 85-112.

Holmes, Clive, 'Women: witnesses and witches', Past \& Present, cxl (Aug., 1993), pp 45-78.

Hopper, Andrew, Black Tom: Sir Thomas Fairfax and the English Revolution (Manchester, 2007).

Horai, Hiro, Medical humanism and natural philosophy: renaissance debates on matter, life and the soul (Leiden, 2011).

Hoskins, W. G., 'Harvest fluctuations and English economic history, 1620-1759', Agricultural History Review, xvi (1968), pp 15-31.

Hotson, Howard, Paradise postponed: Johann Heinrich Alsted and the birth of Calvinist millenarianism (Dordrecht, 2000).

Hughes, Anne, 'Puritanism and gender' in, John Coffey and Paul Lim (eds), The Cambridge companion to Puritanism (Cambridge, 2008), pp 294-308.

Hunt, William, The Puritan moment: the coming of revolution in an English county (Massachusetts, 1983).

Hunter, Michael, Science and society in Restoration England (Cambridge, 1981).

Hunter, Michael, 'The Royal Society and the decline of magic', Notes \& Records of the Royal Society, lxv (Jan., 2011), pp 103-19.

Hutton, Ronald, The pagan regions of the ancient British Isles: their nature and legacy (Oxford, 1998).

Hutton, Ronald, The triumph of the moon: a history of modern pagan witchcraft (Oxford, 1999).

Hutton, Ronald, 'Modern pagan witchcraft' in, Bengt Ankarloo and Stuart Clark (eds), Witchcraft and magic in Europe: the twentieth century (6 vols, London, 1999), vi, pp 21-31.

Ingram, Martin, Church courts, sex and marriage in England, 1570-1640 (Cambridge, 1987, reprinted 2003).

Jackson, Louise, 'Witches, wives and mothers: witchcraft persecution and women's confessions in seventeenth-century England', Women's History Review, iv, no. 1 (1995), pp 63-84. 
Johnstone, Nathan, The devil and demonism in early modern England (Cambridge, 2006).

Jones, A. G. E., 'Plagues in Suffolk in the seventeenth century', Notes \& Queries, cxcviii (Sept., 1953), pp 384-6.

Jones, J. O., 'Matthew Hopkins, witchfinder (d.1647)' in, Thomas Seccombe (ed.), Lives of twelve bad men: original studies of eminent scoundrels by various hands (London, 1894), pp 55-66.

Jue, Jeffrey, 'Puritan millenarianism in Old and New England' in, John Coffey and Paul Lim (eds), The Cambridge companion to Puritanism (Cambridge, 2008), pp 259-76.

Kelsey, Sean, 'Rich, Robert, second earl of Warwick (1587-1658), colonial promoter and naval officer', ODNB (Oxford, 2004) (Available at doi:10.1093/ ref:odnb/23494) (Accessed: July, 2018).

Kempf, Damien, and Maria Gilbert, Medieval monsters (London, 2015).

Kent, E. J., 'Masculinity and male witches in Old and New England, 1593-1680', History Workshop Journal, 1x, no. 1 (Autumn, 2005), pp 69-92.

Kent, E. J., Cases of male witchcraft in Old and New England, 1592-1692 (Turnhout, 2013).

Keynes, Geoffrey, 'William Harvey and the witches' in, John Carey (ed.), Eyewitness to science (Massachusetts, 1997), pp 17-22.

Kieckhefer, Richard, Magic in the middle ages (Cambridge, 1989).

Killeen, Kevin, The political Bible in early modern England (Cambridge, 2017).

Kittredge, George, Witchcraft in Old and New England (Cambridge, 1929).

Koslofsky, Craig, 'Knowing skin in early modern Europe, c. 1450-1750', History Compass, xii, no. 10 (2014), pp 794-806.

Kounine, Laura, “The devil used her sins": despair, confession and salvation in a seventeenth-century witch-trial', History of emotions: insights into research (Jan., 2014), pp 1-4.

Larner, Christina, Enemies of God: the witch-hunt in Scotland (London, 1981).

Larner, Christina, Witchcraft and religion: the politics of popular belief (Oxford, 1984).

Laurence, Anne, 'Women's work and the English Civil War', History Today, xlii (June, 1992), pp 20-5.

Lehner, Ernst and Johanna, Devils, demons and witchcraft: 244 illustrations for artists (New York, 1971).

Levack, Brian (ed.), New perspectives on witchcraft, magic and demonology: gender and witchcraft (6 vols, London, 2001), i, iv.

Levack, Brian, The witch-hunt in early modern Europe (3rd edition, Harlow, 2006).

Levack, Brian, The Devil within: possession \& exorcism in the Christian West (Cornwall, 2013).

Levack, Brian (ed.), The Oxford handbook of witchcraft in early modern Europe and colonial America (Oxford, 2013).

Liberman-Cuenca, Esther, 'Belief and practice: ideas of sorcery and witchcraft in late medieval England' (MA thesis, California State University, 2007).

'The Library of Archbishop Samuel Harsnett: a report', Research Tools, no. 3 (Colchester, University of Essex, Department of History, December 2012), pp 1-51 (Available at: www.essex.ac.uk/history/research/papers.aspx (Accessed: Feb., 2016).

Lindow, John, 'The challenge of folklore to medieval studies', Humanities, vii, no. 1 (Feb., 2018), pp 1-9. 
Linton, Eliza, Witch stories (London, 1861).

Losse, John, A historical introduction to the philosophy of science (Oxford, 1972).

MacDonald, Michael, Mystical bedlam: madness, anxiety, and healing in seventeenth-century England (Cambridge, 1981).

Macfarlane, Alan, Witchcraft in Tudor and Stuart England: a regional and comparative study (London, 1970, 2nd edition 2008).

Macfarlane, Alan, The family life of Ralph Josselin a seventeenth-century clergyman: an essay in historical anthropology (London, 1970).

Mackay, Charles, Memoirs of extraordinary popular delusions (3 vols, London, 1841), ii.

Maranda, Eric Laurent, Victoria Lim, Richa Taneja, Brian Simmons, Penelope J. Kallis and Joaquin Jimenez, 'Witches and warts', Journal of American Medical Association, Dermatology, clii, no. 8 (Aug., 2016), p. 877.

Marshall, Peter, Reformation England, 1480-1642 (2nd edition, New York, 2012).

Martin, Shannon E., and David A. Copeland (eds), The function of newspapers in society: a global perspective (Westport, 2003).

Matteoni, Francesca, 'Blood beliefs in early modern Europe' (PhD, University of Hertfordshire, 2009).

Maxwell-Stuart, P. G., 'Astrology, magic and witchcraft' in, Andrew Hatfield (ed.), The Oxford handbook of English prose, 1500-1640 (Oxford, 2013), pp 326-42.

McDonald, S. W., 'The Devil's mark and the witch-prickers of Scotland', Journal of the Royal Society of Medicine, xc (Sept., 1997), pp 507-11.

Michelet, Jules, La sorcière: the witch of the middle age, transl. L. J. Trotter (London, 1863).

Midelfort, H. C. Erik, Witch hunting in southwestern Germany, 1562-1684 (Stanford, 1972).

Millar, Charlotte-Rose, 'Sleeping with devils: the sexual witch in seventeenthcentury England' in, Marcus Harmes and Victoria Bladen (eds), Supernatural and secular power in early modern England (Farnham, 2015), pp 207-31.

Millar, Charlotte-Rose, Witchcraft, the devil, and emotions in early modern England (London, 2017).

Miller, Ian, 'A witchcraft accusation in 17th century Reading', Berkshire Family History Society Journal (2018), pp 1-12.

Miller, John, 'The long term consequences of the English Revolution: economic and social development' in, Michael Braddick (ed.), The Oxford handbook of the English Revolution (Oxford, 2015), pp 501-17.

Mitchell, John and John Dickie, The philosophy of witchcraft (Paisley, 1839).

Mittman, Asa, Maps and monsters in medieval England (New York, 2006).

Mittman, Asa, and Susan Kim, 'Monsters and the exotic in medieval England' in, Elaine Treharne, Greg Walker and William Greene (eds), The Oxford handbook of medieval English literature (Oxford, 2010), pp 677-706.

Moore, Susan Hardman, 'For the mind's eye only: puritans, images and "the gold mines of Scripture"', Scottish Journal of Theology, lix, no. 3 (2006), pp 281-96.

Moore, Susan Hardman, 'Reformed theology and puritanism' in, Paul Nimmo and David Ferguson (eds), The Cambridge companion to reformed theology (Cambridge, 2016), pp 199-214.

Monter, E. William, Witchcraft in France and Switzerland (London, 1976).

Morrill, John (ed.), Reactions to the English Civil War, 1642-1649 (London, 1982). 
Morrill, John (ed.), The impact of the English Civil War (London, 1991).

Muchembled, Robert, A history of the Devil from the middle ages to the present (Cornwall, 2003).

Murray, Margaret, The witch-cult in western Europe: a study in anthropology (London, 1921).

Nadler, Steven (ed.), Blackwell companion to early modern philosophy (Oxford, 2008).

Narveson, Kate, Bible readers and lay writers in early modern England: gender and self-definition in an emergent writing culture (Farnham, 2012).

Nimmo, Paul, and David Ferguson (eds), The Cambridge companion to reformed theology (Cambridge, 2016).

Notestein, Wallace, A history of witchcraft in England from 1558 to 1716 (Washington, 1911).

Oates, Rosamund, 'Sermons and sermon-going in early modern England', Reformation, xvii, no. 1 (2012), pp 199-212.

'Officers and members', and 'Annual reports', Transactions of the Baptist Historical Society, iii, no. 4 (Sept., 1913), pp 257-62.

Oldridge, Darren, The devil in early modern England (Stroud, 2004).

Oldridge, Darren, Strange histories: the trial of the pig, the walking dead, and other matters of fact from the medieval and renaissance worlds (London, 2007).

Oldrige, Darren, 'Fairies and the Devil in early modern England', The Seventeenth Century Journal, xxxi, no.1 (2016), pp 1-15.

Peacey, Jason, Print and public politics in the English Revolution (Cambridge, 2013).

Peacey, Jason, 'Revolution in print' in, Michael Braddick (ed.), The Oxford handbook of the English Revolution (Oxford, 2015), pp 277-98.

Poole, Robert (ed.), The Lancashire witches: histories and stories (Manchester, 2002).

Purkiss, Diane, The witch in history: early modern and twentieth-century representations (London, 1996, reprinted 2005).

Purkiss, Diane 'Desire and its deformities: fantasies of witchcraft in the English civil war', The Journal of Medieval and Early Modern Studies, xxvii, no. 1 (1997), pp 103-32.

Purkiss, Diane, 'Sounds of silence: fairies and incest in Scottish witchcraft stories' in, Stuart Clark (ed.), Languages of witchcraft: narrative, ideology and meaning in early modern culture (Basingstoke, 2001), pp 81-98.

Purkiss, Diane, The English Civil War: a people's history (London, 2007).

Purvis, J. S., Tudor parish documents of the diocese of York (Cambridge, 1948).

Quaife, G. R., Wanton wenches and wayward wives: peasants and illicit sex in early seventeenth century England (London, 1979).

Quaife, G. R., Godly zeal and furious rage: the witch in early modern Europe (Worcester, 1987).

Raymond, Joad, The invention of the newspaper: English newsbooks, 1641-1649 (Oxford, 1996).

Raymond, Joad (ed.), 'The development of the book trade in Britain' in, The Oxford handbook of popular print culture in Britain and Ireland to 1660 (9 vols, Oxford, 2011), pp 59-75, i.

Raymond, Joad, 'News Writing' in, Andrew Hadfield (ed.), The Oxford handbook of English Prose 1500-1640 (Oxford, 2013), pp 401-5. 
Register of admissions to the Honourable Society of the Middle Temple (from the fifteenth century to 1944), ed. H. A. C. Sturgess (3 vols, London, 1949), i (Available at: www.middletemple.org.uk/library-and-archive/archive-information-andcontacts/register-of-admissions).

Riddell, William, 'First execution for witchcraft in Ireland', Journal of Criminal Law and Criminology, vii, no. 6 (1917), pp 828-37.

Rivett-Carnac, J. H., 'Witchcraft: the Rev. John Lowes', Notes \& Queries, ix, series 8 (London, March, 1896), p. 223.

Rogers, Pat, 'Addison, Joseph (1672-1719)', ODNB (Oxford, 2004) (Available at doi:10.1093/ref:odnb/156) (Accessed: Dec., 2019).

Roper, Lyndal, Oedipus and the devil: witchcraft, sexuality and religion in early modern Europe (New York, 1994, reprinted 2005).

Rosen, Barbara, Witchcraft in England, 1558-1618 (Amherst, 1991).

Rowlands, Alison (ed.), Witchcraft and masculinities in early modern Europe (Basingstoke, 2009).

Rublack, Ulinka, and Pamela Selwyn, 'Fluxes: the early modern body and the emotions', History Workshop Journal, liii, no. 1 (Jan., 2002), pp 1-16.

Rushton, Peter, 'Women, witchcraft and slander in early modern England: cases from the church courts of Durham, 1560-1675', Northern History, xviii, no. 1 (1982), pp 116-32.

Russell, Bertrand, History of western philosophical thought and its connection with political and social circumstances from the earliest times to the present day (London, 1946).

Russell, Jeffery B., Witchcraft in the middle ages (London, 1972).

Russell, Jeffrey B., Lucifer: the devil in the middle ages (New York, 1984).

Ruston, Alan, 'Gordon, Alexander', ODNB (Oxford, 2004) (Available at doi:10.1093/ref:odnb/37470) (Accessed: Dec., 2019).

Saif, Laura, The Arabic influences on early modern occult philosophy (Basingstoke, 2015).

Salisbury, Joyce, The beast within: animals in the middle ages (London, 1994).

Salmon, Marylynn, 'The cultural significance of breastfeeding and infant care in early modern England and America', Journal of Social History, xxviii, no. 2 (1994), pp 247-69.

Saunders, Conie, Magic and the supernatural in medieval English romances (Cambridge, 2010).

Sax, Boria, 'The magic of animals: English witch trials in the perspective of folklore', Anthroös, xxii, no. 4 (2009), pp 317-32.

Schneider, Eric, 'Real wages and the family: adjusting real wages to changing demography in pre-modern England', Explorations in Economic History, 1, no. 1 (Jan., 2013), pp 99-115.

Schulte, Rolf, Man as a witch: male witches in Central Europe (Basingstoke, 2009).

Scott, Sir Walter, Letters on demonology and witchcraft (Edinburgh, 1830).

Serpell, James, 'Guardian spirits or demonic pets: the concept of the witch's familiar in early modern England, 1530-1712' in, Angela Creager and William Jordan (eds), The animal/human boundary: historical perspectives (New York, 2002), pp 157-90.

Seymour, John, Irish witchcraft and demonology (Dublin, 1913).

Shapiro, Barbara, A culture of fact: England, 1550-1720 (London, 2000).

Sharpe, J. A., Crime in seventeenth-century England: a county study (Cambridge, 1983). 
Sharpe, James, Instruments of darkness: witchcraft in early modern England (Philadelphia, 1997).

Sharpe, James, The bewitching on Anne Gunter: a horrible and true story of football, witchcraft, murder and the King of England (London, 1999).

Sharpe, James, Witchcraft in early modern England (London, 2001).

Sharpe, James, 'The witch's familiar in Elizabethan Essex' in, G. W. Bernard and S. J. Gunn (eds), Authority and consent in Tudor England (Aldershot, 2002), pp 219-32.

Sharpe, James, and Richard Golden (eds), English witchcraft, 1560-1736 (6 vols, London, 2003).

Sharpe, James, 'In search of the English sabbat: popular conceptions of witches' meetings in early modern England', Journal of Early Modern Studies, ii (2013), pp 161-83.

Shipps, Kenneth, 'The "Political Puritan"', Church History, xlv, no. 2 (1976), pp 196-205.

Simpson, R. S., 'Murray, Margaret Alice (1863-1963)', ODNB (Oxford, 2004) (Available at: doi:10.1093/ref:odnb/35169) (Accessed: December, 2019).

Siraisi, Nancy, 'Medicina practica: Girolamo Mercuriale as teacher and textbook author' in, Emidio Campi, Simone de Angelis, Anja-Silvia Goeing and Anthony Grafton (eds), Scholarly knowledge: textbooks in early modern Europe (Geneva, 2008), pp 287-305.

Spinks, Jennifer, Monstrous births and visual culture in sixteenth-century Germany (London, 2009).

Sneddon, Andrew, Witchcraft and Whigs: the life of Bishop Francis Hutchinson, 1660-1739 (Manchester, 2008).

Sneddon, Andrew, Witchcraft and magic in Ireland (Basingstoke, 2015).

Snobelen, Stephen, 'Lust, pride, and ambition: Isaac Newton and the Devil' in, J. E. Force and Sarah Hutton (eds), Newton and Newtonianism: new studies (Dordrecht, 2004), pp 151-81.

Stephens, Walter, Demon lovers: witchcraft, sex and the crisis of belief (Chicago, 2002).

Stoyle, Mark, The black legend of Prince Rupert's dog: witchcraft and propaganda during the English Civil War (Liverpool, 2011).

Suhr, Carla, Publishing for the masses: early modern English witchcraft pamphlets (Helsinki, 2011).

Summers, Montague, The history of witchcraft and demonology (London, 1926).

Summers, Montague, The geography of witchcraft (London, 1927).

Tay, Edwin, 'Puritan demonology in the culture of "the Godly", Church \& Society in Asia Today, xv, no. 3 (2012), pp 145-51.

Thirsk, Joan, The rural economy of England: collected essays (London, 1984).

Thomas, Courtney, “Not having God before his eyes”: bestiality in early modern England', The Seventeenth Century, xxvi, no. 1 (2011), pp 149-73.

Thomas, Keith, Religion and the decline of magic: studies in popular beliefs in sixteenth-and seventeenth-century England (London, 1971, reprinted 1985).

Thomas, Keith, Man and the natural world: changing attitudes in England, 15501800 (London, 1984).

Thompson, E. P., 'Anthropology and the discipline of historical contexts', Midland History, i, no. 3 (1972), pp 41-55.

Thorpe, James, Henry Edwards Huntington: a biography (Berkeley, 1994).

Timbers, Frances, 'Witches sect or prayer meeting?: Matthew Hopkins revisited', Women's History Review, xvii, no. 1 (2008), pp 21-37. 
Tourney, Garfield, 'The physician and witchcraft in Restoration England', Medical History, xvi, no. 2 (1972), pp 143-55.

Trevor-Roper, Hugh, The crisis of the seventeenth century: religion, the Reformation and social change (New York, 1967).

Tubb, Amos, 'Independent presses: the politics of print in England during the late 1640s', The Seventeenth Century Journal, xxvii, no. 3 (2012), pp 287-312.

University of Glasgow, Catalogue of the Ferguson Collection of books mainly relating to alchemy, chemistry, witchcraft and Gipsies (Glasgow, 1943, Supplement, 1955).

Valletta, Fredrick, Witchcraft, magic and superstition in England, 1640-70 (Farnham, 2000).

Voltmer, Rita, 'The witch in the courtroom: torture and the representation of emotion' in, Laura Kounine and Michael Ostling (eds), Emotions in the history of witchcraft (London, 2016), pp 97-116.

Wallace, Dewey, Puritans and predestination: grace in English Protestant theology (Chapel Hill, 1982).

Walsham, Alexandra, Providence in early modern England (Oxford, 1999).

Walter, John, Understanding popular violence in the English Revolution: the Colchester plunderers (Cambridge, 1999).

Warburton, Greg, 'Gender, supernatural power, agency and the metamorphoses of the familiar in early modern pamphlet accounts of English witchcraft', Parergon, xx, no. 2 (2003), pp 95-118.

Waters, Thomas, 'Magic and the British middle classes, 1750-1900', Journal of British Studies, liv, no. 3 (July, 2015), pp 632-53.

Watt, Tessa, Cheap print and popular piety 1550-1640 (Cambridge, 1991).

Weber, Eugen, Apocalypses: prophecies, cults \& millennial beliefs through the ages (Toronto, 1999).

Weber, Timothy, 'Millennialism' in, Jerry Walls (ed.), The Oxford handbook of eschatology (Oxford, 2008), pp 365-83.

Weston, David, 'Ferguson, John (1838-1916)', ODNB (Oxford, 2004) (Available at doi:10.1093/ref:odnb/53857) (Accessed: June, 2018).

Wheatley, Henry, Prices of books: an inquiry into the changes in the prices of books which have occurred in England ay different periods (London, 1898).

Wilby, Emma, 'The witch's familiar and the fairy in early modern England and Scotland' Folklore, cxi, no. 2, (Oct., 2000), pp 283-305.

Wilby, Emma, Cunning folk and familiar spirits: shamanistic visionary traditions in early modern British witchcraft and magic (Eastbourne, 2005).

Williams, Sarah, Damnable practices: witches, dangerous women, and music in seventeenth-century English broadside ballads (Farnham, 2015).

Williams, Sarah, "Living past monuments": memory, music and theatre in the seventeenth-century English broadside ballad' in, Linda Austern, Candace Bailey and Amanda Winkler (eds), Beyond boundaries: rethinking music circulation in early modern England (Bloomington, 2017), pp 96-113.

Willis, Deborah, Malevolent nurture: witch-hunting and maternal power in early modern England (Ithaca, 1995).

Winsham, Willow, England's witchcraft trials (Barnsley, 2018).

Wright, Thomas, Narratives of sorcery and magic, from the most authentic sources (2 vols, London, 1851), ii.

Yale, Elizabeth, 'Marginalia, commonplaces, and correspondence: scribal exchange in early modern science', Studies in History and Philosophy of Biological and Biomedical Sciences, xlii (2011), pp 193-202. 